\title{
Ethnobotanical Study of Medicinal Plants in Nagelle Arsi District, West Arsi Zone of Oromia, Ethiopia
}

\author{
Marshet Gijan Gemedo Dalle* \\ 1.Ethiopian Biodiversity Institute, Addis Ababa Ethiopia \\ 2.Center for Environmental Science, Addis Ababa University, P. O. Box 80119, Addis Ababa, Ethiopia
}

\begin{abstract}
Ethnobotanical study was conducted in Nagelle Arsi District, Ethiopia with the objective of identifying and documenting medicinal plants, associated indigenous knowledge and ethnobotanical practices of local communities. Household survey using semi-structured interviews, key informant interview, group discussions, field observations and market survey methods were used for data collection. A total 17 kebeles (smallest administrative unit) out of the 34 in the District were selected for this study, from which 90 informants for the household survey were interviewed. Eight key informants per each site were selected following purposive sampling method. Qualitative and quantitative statistical methods, priority ranking, paired comparison, direct matrix ranking, informant consensus and percentage distribution were used for data analysis. A total of 102 medicinal plants belonging to 85 genera and 55 families were collected and identified including four endemic plants to Ethiopia. The finding indicated that 65 species were used for treating human diseases, 31 species for both human and livestock diseases and 7 for livestock diseases. Species used for treating cancer, blood pressure, malaria, diabetes, hemorrhoids and prostate problems were identified and documented. Seventeen medicinal plants were found to be wild edibles. Commonly used plant parts were leaves followed by roots and barks. The common routes of administration were oral followed by dermal. It was concluded that although the District was rich in medicinal plants, these species have been under serious threat due to agricultural expansion, deforestation, forest degradation and over harvesting for different purposes including firewood collections. Therefore, urgent conservation measures applying in-situ and ex-situ methods and strengthening sustainable management of natural forest were recommended.
\end{abstract}

Keywords: Biodiversity conservation, indigenous knowledge, medicinal plants, Nagelle Arsi, sustainable use.

DOI: $10.7176 / \mathrm{JNSR} / 9-13-01$

Publication date:July $31^{\text {st }} 2019$

\section{Introduction}

Ethnobotanical studies are useful in documenting, analyzing, and communicating knowledge and practices that would contribute to potential bioprospecting and production of commercial medicine for the betterment of human society. Indigenous and local communities have developed their own locality specific knowledge on plant use, management, and conservation (Balick \& Cox 1996). Plants are indispensable and most important sources of both preventive and curative traditional preparations for human beings and for their animals since ancient times. Indigenous knowledge and practices have been major factors for the use and domestication of many multipurpose species. Local communities in developing countries such as Ethiopia are still dependent on locally available medicinal plants as about $80 \%$ of the country's population live in rural areas where availability and affordability of modern medicines remain out of reach for many families. Limited access to health stations, low number of nurses and medical doctors in those rural areas and lack of modern medicine in most clinics have been common features in many rural areas of Ethiopia.

As a result, indigenous and local communities developed and still making use of their rich knowledge on the taxonomy and use medicinal plants, preparations and applications of local medicines in their vicinity. Medicinal plants have been in use in traditional medicine and contemporary and alternative medicine both in developing and developed countries; thus a large number of people habitually use such medication. And its popularity also stems from the efficacy of the treatment and relative safety, with few or no side effects. Herbal medicines, because of their decentralized nature, are easily and quickly available, relatively cheaper and sustainable alternative to synthetic drugs and pharmaceuticals (Aziz et al. 2018; Wendimu et al. 2007).

Indigenous and local communities in Ethiopia have been using medicinal plants for treating various ailments of both human and livestock for centuries. The strong linkage between medicinal plants and indigenous knowledge has been documented by many authors. Ethnobotanical studies have been widely recognized as critical to identify threatened plants so that appropriate conservation measures are taken in time (Lulekal et al. 2008). However, conservation status of these plants has become a serious concern in many rural areas. The current loss of medicinal plants in the country due to climate change and anthropogenic factors has also negative impacts on indigenous knowledge of the communities that has been associated with these plants and their habitats. Deforestation and forest degradation, agricultural expansion, loss of grasslands and woodlands, over-harvesting, agricultural practices in marginal lands, overgrazing and urbanization are some of the major factors threatening biodiversity in 
general and medicinal plants and their ecosystems in particular. Although these factors are common in most parts of Ethiopia, the situation in Nagelle Arsi is unique in two ways: there has been high demand for firewood widely used for the production of local alcohol called "Arake" and suitability of the agroecology has attracted many farmers from different regions of the country further exacerbating conversion of grasslands, woodlands and forest ecosystems into agricultural fields for crop cultivation. Other major factors causing loss of biodiversity in the area include illegal logging and timber production.

In the face of these threatening factors, there has been high need to document indigenous knowledge of local communities on the taxonomy, use and applications of medicinal plants. In Ethiopia, documentation of medicinal plants and associated indigenous knowledge has been incomplete (Balemie et al. 2004) as little emphasis has been given to ethnobotanical studies over the past decades (Giday 1999). However, there have been some efforts in investigating medicinal plants and indigenous knowledge on use and management of plant medicinal plant resources in recent years. We noted that limited data is available on medicinal plants and their uses in Nagelle Arsi District. Therefore, this study aimed at contributing to filling existing gap in data and knowledge on ethno botany and local phytomedicine preparations and applications in Nagelle Arsi District, West Arsi Zone of Oromia Regional National State, Ethiopia with the objectives of documenting medicinal plants and their conservation status; compiling data on uses of medicinal plants; documenting indigenous knowledge of local communities and collecting voucher specimen of medicinal plants thereby contributing to enriching collections in the National Herbarium of Ethiopia.

\section{Materials and Methods}

\subsection{Description of the study area}

Nagelle Arsi District is located in West Arsi Zone of Oromia National Regional State, Ethiopia. Langanno, Shalla and Abijata lakes are found in this District. The capital town of the District is also called Nagelle Arsi which is located at about $225 \mathrm{kms}$ away from of Addis Ababa to South between $7^{0} 13^{\prime} 58.8^{\prime \prime} \mathrm{N}$ to $7^{0} 29^{\prime} 24.4^{\prime \prime} \mathrm{N}$ and $38^{0} 43^{\prime}$ $10.9^{\prime \prime} \mathrm{E}$ to $38^{0} 78^{\prime} 07.5^{\prime \prime} \mathrm{E}$ (Figure1). The altitudinal variation of the Woreda ranges from 1614 to 2540 meters above sea levele (masl).

\subsubsection{Climate (Rainfall and Temperature)}

Nagelle Arsi District is classified into three agroecological zones based on altitude. These are low, mid and high altitude climatic zones. Average annual temperature varies from $16-25^{\circ} \mathrm{C}$ and rainfall varies between $500-1500$ $\mathrm{mm}$.

\subsubsection{Vegetation}

The natural vegetation of the area has beed broadly classified as dry evergreen montane forest and Acacia woodland vegetation type (Demissew \&Friis 2009). Principal categories of forest vegetation include high forest from approximately $2100 \mathrm{~m}$ to $2450 \mathrm{~m}$, Bamboo thicket from 2450 to $2650 \mathrm{~m}$ and low forest and woodland at the edge of and on the plain above the steep slopes occupied by bamboo. Large trees include Podocarpus falcatus, Celtis africana, Olea capensis and Pruns africana. Furthermore, understory species include Brucea antidysenterica, Cassipourea malosana, Lepidotrichilia volkensii, Maytenus spp., and Vepris dainellii, Albizia schimperiana, Calpurnia aurea, Cordia africana, Olea europea subsp.cuspidata are frequent at mountain edges (Dalle 2015).

\subsection{Ethnobotanical Data Collection}

Following reconnaissance survey, ethnobotanical data was collected from December 2016 to January 2017. During the survey, three representative agroecologies were selected using a stratified sampling technique. Altitude was used to stratify the study area in the district. In the second stage, proportional allocation techniques were used to determine the number of sample kebeles from each agroecology. Stratified and random sampling techniques were employed tor select study kebeles and informants. Accordingly, a total of 17 kebeles (50\% of the total kebeles) were selected and separated by altitude: high, medium and low altitude ranges. Concerning number of kebeles sampled, six, eight and three were selected from high, medium and low altitudinal ranges, respectively. Relatively more samples were taken from the medium altitude category because of the fact that most of the kebeles in Nagelle Arsi District belong to this category.

Furthermore, a preliminary survey was conducted on some kebeles to sketch out the overall status of medicinal plant distribution and indigenous knowledge in the study area. Following this, the study sites within the agroecology were systematically selected in accordance with their status of forest coverage and population settlement.

\subsubsection{Informants selection}

Following identified sample areas, informants were selected for the ethnobotanical study from the selected 17 kebeles using lottery methods. This was done by considering a list of households and their recognized indigenous knowledge on medicinal plants and their uses in each kebeles. Traditional healers were selected systematically with the help of local elders and administrators. As the result, a total of 90 informants (48 males and 42 females) 
were selected from the age of 18 and above. Age group of the informants consists of young (18-35), middle (36$49)$ and elders $(>50)$.

\subsubsection{Data collection}

Semi-structured interviews were conducted following Cotton (1996). These interviews were made with the help of translators who were conversant with the local language (Afan Oromo). But before conducting the interview, open discussions were held with to get consensus from the informants and also to clearly explain the objectives of the study. After consensus was reached, the interviews were conducted and data collected. The interviews were done mostly in the field in order to avoid the probable confusions with regard to the identity of medicinal plants. Moreover, the morphological characteristics, habitats and habits of medicinal plants were observed and recorded during and after the interviews. To correlate the common name with its scientific name, we collected plant specimens in the field, showed them to those interviewed in order to confirm the correct name of each uses of each species.

Group discussions were conducted in three different agroecological zones with number of 30 local community members which included eight traditional healers.

Guided field walks were also included in data collection aimed at observing, feeling, smelling and tasting different medicinal plants with the help of local informants. These ethnobotanical data collections were found to be more explanatory than talking without visualizing the plants. On the other hand, this guided field walk was used as an opportunity to record data on habitat, habit, and appearance, relation with other species and also for collecting voucher specimen.

Furthermore, market survey was made by selecting representative market places of the study area. Different sellers are interviewed and recorded the type of herbal drug sold in the market and multipurpose medicinal plants such as timber, farm implement, walking stick, food, spices, forage, wild edible fruits and traditional drug. And also data degree of utilization, variety, and economic importance of medicinal plants for the local community were collected.

\subsubsection{Plant specimens collection and Identification}

Herbarium samples of the listed medicinal plants were collected and recorded with the help of informants. The voucher specimen were coded, pressed, properly dried and taken to the National Herbarium of Addis Ababa University. Preliminary identification was also done in the field and further confirmation and identification of unknown species was done by using taxonomic key, comparison of authenticated voucher specimens deposited in Addis Ababa University herbarium and by the help of experts. Nomenclature of plant species follows published volumes of the Flora of Ethiopia and Eritrea.

\subsection{Data analysis}

Descriptive statistical method such as percentage and frequency distribution were employed to analyze and summarize the data on medicinal plants and associated knowledge. The relevant information collected and reported by local people, plant habit, plant parts used, methods of preparation, dosages and route of applications were analyzed through descriptive statistics.

Information provided by different informants was calculated using informants' consensus factor (ICF) following Leonti et al. (2001). Seven use-categories were used for that purpose. An ICF value close to one is taken as an indication of high intra-cultural consensus, that is, more healers use the same plant species, where as, a value close to zero as a low probability of similarity in use of plants by different informants.

Preference or priority ranking was calculated for seven selected medicinal plants important to treat human and livestock stomach problem and degree of scarcity in each Kebeles following Martin (1995). These plants were chosen based on the information obtained from key informants. Eight key informants from each study site were selected and invited to rank these plants. Accordingly, each informant given the highest value for the most effective medicinal plants used by local community to treat stomach problem and least scarce plant species, and the lowest value for the plants species that is the least preferred medicinal plants and commonly available (not scarce). The values assigned by each key informant for each of the seven medicinal plants were summed up and the total scores were calculated and ranked.

To compare the relative importance of those medicinal plants in multipurpose role and dominant use, a use value ranking was done following Martin (1995) and Cotton (1996). Eight key informants were chosen to give use value to each medicinal plant species. The use values were given as five $=$ best, four $=$ very good, three $=$ good, two $=$ less used, one $=$ least used, zero $=$ not used. Based on the relative benefits obtained from each plant species, each key informant gave scores for each use value for six multipurpose medicinal plants and then average value (average score) of the total value of each use diversity for each species in each study site were summed up and ranked to compare the degree of preference and the various uses of the plant species in each study site.

Paired comparison is another analytical technique used for evaluating the degree of preferences or levels of importance of certain selected medicinal plants. After random arrangement the pairs ordered alphabetically and numbered them sequentially. Five of the most important medicinal and wild edible plants of the study areas (based 
on their high use values as perceived and suggested by most informants of each study area) were selected and paired comparison was done following Martin (1995).

\section{Results}

\subsection{Medicinal plants diversity and associated Knowledge}

A total of 102 medicinal plants belonging to 85 genera and 55 families that were used for treating human and livestock ailments were collected and identified (Appendix 1). Four medicinal plants endemic to Ethiopia were also identified during this study. Top five Plant Families with the highest number of medicinal plants included Fabaceae (seven species in seven general), Asteraceae (seven species in six genera), Lamiaceae (seven species in four genera), Solonaceae (six species in four genera) and Euphorbiaceae (five species in three genera). Trees and shrubs were the most commonly used medicinal plants comprising of $71.6 \%$ (shrubs represented by 37 species and tress 36 species) followed by herbs (23.5\% or represented by 24 species). Besides, three climbers and two lianas were used as medicinal plants in the study area (Appendix 1).

Most identified and documented species (65 species or 63.74\%) were used for treating human diseases, 30 species $(29.40 \%)$ for treating both human and livestock diseases and seven species $(6.86 \%)$ were used for treating only livestock diseases.

Out of the 90 informants participated in this study, males were $48(53 \%)$ and females were $42(47 \%)$. Comparison of their indigenous knowledge showed that women were more knowledgeable on medicinal plants collected from homegradens and men were better on species collected from wild. Furthermore, comparison between old (both men and women as one group (and young including boys and girls) showed that elders had better knowledge on medicinal plants than young inhabitants. It was documented that traditional healers do transfer their knowledge to the eldest son in their family and try to keep their knowledge as top secret.

\subsection{Plant parts used for preparing traditional medicine}

Commonly used plant parts by local communities to treat human and livestock disease included leaves, roots, barks and seeds. Leaves were the most widely used plant parts $(46.66 \%)$ followed by roots and barks (Table 1$)$. The total number of species in Table 1 was greater than the total number of documented species showing the fact that different parts of the same plant were used for preparing remedy for different treatments (Appendix 2).

\subsection{Types of human and livestock diseases treated with a number of species}

Local communities used one or many species to prepare remedies. This study documented that a total of 30 human diseases were treated with a total of 65 plant species using 168 different types of preparations. Some plant species mixed with others plant species or mixtures of various substances were used to treat number of ailments (Table 2 and Appendix 2).

Similarly, the study showed that 13 livestock diseases were found to be treated with a total of 37 plant species and 68 preparations. For example, Anthrax is treated with 25 different plant species (Table 3 and Appendix 2).

\subsection{Preparations, routes of administration and dosages}

According to informants' perception, $85 \%$ of herbal preparations were from freshly collected plant materials followed by $15 \%$ of dried parts of the plants. There were number of mixtures using hot or cold water, coffee or milk. On the other hand, it was perceived that as volume of solvents increase, the time required for healing increases, reduces uncomfortable taste and limit adverse side effects. Methods of preparation included crushing and boiling, powdering for chewing, squeezing, grinding, smoking, washing, rubbing and cream treatments (Table 4 and Appendix 2). Traditional healers also used mixing two or more medicinal plants to treat selected ailments. For example, leaves of Artemisia rehan was mixed with bark of Croton macrostachyus for the treatment of evil eyes.

Different applications were reported by the informants in the treatment of various human and livestock ailments (Appendix 2). The commonly recorded routes of administration were oral $(53.33 \%)$, followed by dermal $(40 \%)$, nasal $(4 \%)$ and optical $(2.66 \%)$. The most preferred mode of administration was oral because it was reported to be more effective for various ailments such as anti-parasites, and anti-bacterial diseases.

Different measuring materials such as glass of water, cup of tea, cup of coffee, tea spoons, and a range of litters were used to determine dosage. Most of the time prescriptions are based on age of the patient, gender; pregnancy status and the amount of remedies given by traditional healers. It was noted that dosages also vary based on indigenous knowledge of individuals. There also variations in time of the day, treatment duration, and mixture of substances. During this study, it was observed that there was a gap in having standard dosage determination among different traditional healers. 


\subsection{Ranking and scoring}

\subsubsection{Medicinal plants used for treatment of types of ailments}

Eight traditional healers were asked to rank seven medicinal plants based on their indigenous knowledge using the degree of treatments for human and livestock disease and effectiveness. Bacterial, parasitic and fungal diseases were reported to be the most common in the study area. Verenonia amygdalina, Croton macrostachyus, and Podocarpus falcatus, were ranked as the most useful medicinal plants for treating parasitic and bacterial diseases (Table 5). Hagenia abyssinica was also pereceived as important medicinal plant for treating tape worm problems.

\subsubsection{Direct matrix ranking}

Using direct matrix ranking method most important multipurpose species were identified. The eight key Informants reached consensus on the rank and score for six highest preferred multipurpose species by considering their value or desirability. Accordingly, Syzgium guineense was found to be the most important multipurpose plant scoring 23 followed by Allophylus abyssinicus and Celtis africana, each scoring 20 (Table 6).

\subsubsection{Paired comparisons for five marketable medicinal plants}

A paired comparison was made for five medicinal plants which have market values in the study area. Ximenia americana and Syzgium guineense were the most highly preferred species (Table 7). These species were found in local market places during their fruiting season and sold to different users. All these species were found in natural forest in the wild.

\subsection{Informant consensus}

Ten most popular plant species agreed upon during the study were selected and ranked. It was observed that some of medicinal plants were in higher demand and most frequently used by the local community than others. Informant consensus analysis showed that Ruta chalepensis (14\%), followed by Ocimum lamiifolium (11\%) and Vernonia amygdalina (13\%) were most importany medicinal plants for treating human ailments (Table 8 ).

\subsection{Economic importance of some medicinal plants in the study area}

In addition to their medicinal value, several plant species recorded during this study do play an important role in economic activities of the local communities. Some wild and cultivated medicinal plants such as Podocarpus falcatus, Agave sisalina, Artemisia rehan, Brassica olearcea, Croton macrostachyus, Coriandrum sativum, Cordia africana, Celtis africana, Ekebergia capensis, Hagenia abyssinica, Lippia adoensis, Moringa stenopetala, Opuntia ficus-indica, Olea europea subsp.cuspidata, Prunus africana, Ricinus communis, Ruta chalepensis, Syzgium guineense, Withania somenifera, are commonly collected and sold in the local or urban market places. Olea europea subsp.cuspidata, and Ekebergia capensis. Withania somenifera, Brassica olearcea are used for smoking traditional bee hives. It was reported that the good smell of smoke from these species has been used to attract bees to bee hives. Several of the documented medicinal plants (for example, Opuntia ficus-indica, Syzgium guineense and Ximenia Americana) are also widely used for human consumption as fruits. Coriandrum sativum, Lippia adoensis, Ruta chalepensis and Brassica olearcea are highly demanded for their condiment value in almost all markets in the study area. Furthermore, a number of tree species were used to produce good quality timber and also for construction including Podocarpus falcatus, Cordia africana, Croton macrostachyus, Celtis africana, Ekebergia capensis, Hagenia abyssinica and Prunus africana. It was recorded that 1 Pices of timber was sold for 250 to300 Ethiopian Birr or \$9-13 US Dollars in local market. Moringa stenopetala was perceived as the most important and widely used plant species for different human ailments and food value and was sold 150 Ethiopian Birr per kg or \$6.12 US Dollars. Artemisia rehan and Ricinus communis werea lso commonly sold in the markets (Table 9).

\subsection{Threats to medicinal plants}

This study covered three different agroecological zones: High lands (altitude range greater than $2500 \mathrm{~m}$ asl), mid altitudinal range $(1500-2500 \mathrm{~m}$ asl $)$ and low lands $(<1500 \mathrm{~m}$ asl $)$. The highest numbers of medicinal plants were collected from altitude between $1500-2500 \mathrm{~m}$ asl followed by low land areas.

According to perception of pastoralists and observations during this study, major factors causing decline of medicinal plants and associated indigenous knowledge included anthropogenic and natural factors (climate change). Agricultural land expansion into forest and grasslands, deforestation, over exploitation of some selected species, land degradation, unsustainable fuel wood and charcoal production and overgrazing were identified as anthropogenic problems in the area. Frequent drought was perceived as natural problem resulting in environmental degradation and loss of species in the lowland areas (Table 10). Ten Informants' ranked their degree of damage. Deforestation was identified as the main threatening factor, followed by agricultural land expansion, fuel wood and charcoal production. 


\section{Discussions}

\subsection{Medicinal Plants Diversity and Habitats Comparisons}

The study result showed that Nagelle Arsi District was rich in medicinal plants having 102 species in 85 genera, and 55 families. Fabaceae, Asteraceae, Lamiaceae and Solonaceae were most important families with many medicinal plants. Similar results were reported from different parts of Ethiopia (Kidane et al. 2018; Lulekal et al. 2008; Lulekal 2013; Yineger 2005). Most medicinal species were found in natural vegetations (wild) in agreement with previous reports (Awas \& Demissew 2009; Gebrehiwot 2010; Issa et al. 2018; Kidane et al. 2018; Lulekal et al. 2008; Yineger 2005) and also indicating the fact that there is high need to conserve and sustainably manage forest ecosystems and grasslands to ensure availability of these medicinal plants for current and future generations.

The habitats of most medicinal plants were mid altitudinal ranges. Similar results have been reported from other study areas (Abdela et al. 2018; Gebrehiwot 2010). On the other hand, this altitudinal range is the most favorable for cereal crop production causing a serious concern of further loss of medicinal plants. This concern need to be noted and practical action is needed on time to minimize the unregulated negative impacts of agricultural expansions on medicinal plants.

\subsection{Indigenous knowledge on the use and parts used of medicinal plants}

Indigenous and local communities rely on herbal medicines to prevent and cure various health problems. Traditional healers have been playing an important role in the primary health care system of the rural community who had less access and could not afford the cost of modern medication. We documented that old and middle aged women and men had more knowledge than the young generation in agreement with previous research findings (Asfaw and Nigatu 1995; Awas 2007; Gemedo-Dalle et al. 2005; Giday et al. 2003; Teklehaymanot 2007). It was also observed that the young generation showed no interest to learn and make use of traditional medicines. The other practical challenge noted during this study was that there was no documentation of indigenous knowledge by traditional healers as the knowledge is transferred orally to the eldest son in the family.

\subsection{Comparative assessments on medicinal plants used for treating ailments, parts used and routes of administration}

This study documented many medicinal plants used for the treatment of both human and livestocks ailments. Most $(63 \%)$ medicinal plants were used for treating human ailments. Similar result was reported (Lulekal et al. 2008) from Mana Angetu District, southeastern Ethiopia where 78.70 \% medicinal plants were used as human medicine. Many medicinal plants identified and recorded during this study were also reported as medicinal in other parts of Ethiopia (Lulekal et al. 2013). Verenonia amygdalina, Croton macrostachyus and Podocarpus falcatus were the most valuable medicinal plants for treating parasitic and bacterial diseases followed by Hagenia abyssinica. Other medicinal plants used for the treatment of human ailments in the study area included Moringa stenopetala for treating blood pressure, Acokanthera schimperi for treating Cancer and Grewia ferruginea for treating diabetes.

Leaves were the most widely used plant parts in Nagelle Arsi District followed by roots in agreement with many studies elsewhere (Giday et al. 2003; Kidane et al. 2018). However, other research results reported roots as the most frequently used plant parts in many areas in Africa (Abdela et al. 2018; Issa et al. 2018; Lulekal et al. 2008; Lulekal et al. 2013).

Shrubs were the most commonly used (43\%) followed by trees $(35 \%)$ and herbs $(22 \%)$. This finding was not in agreement with report by Isa et al. (2018) who documented that the dominant medicinal plants in Algoz area, South Kordofan, Sudan were herbs followed by trees and shrubs. The dominance of trees and shrubs in Nagelle Arsi District could be an indicator of high degree of unregulated agricultural expansion into high forests, woodland and grasslands resulting in loss of herbaceous species.

The majority of remedies in the study area were prepared from fresh materials of leaves, barks, roots, and fruits of the plants. Most of them were prepared by crushing, boiling, chewing, smoking, grinding, and powder forms.

The most commonly used route of administration was oral followed by dermal. Oral administration was preferred because it was believed to be more effective in agreement with research results from somewhere else (Gebrehiwot 2010; Giday et al. 2003).

It was also observed that traditional medicine was prescribed or given based on the age of the patient, gender and pregnancy status. And also amount or volume of remedies given by traditional healers varies according to their respective indigenous knowledge. It was also noted that dosage still remains serious concern as there was diffrences among healers for treating the same kind of health problem by applying different dossages of the same herbal medicine as there was no established standard of measurement. Similar problem was also reported from other places (Ashagre et al. 2016; Gebrehiwot 2010; Lulekal et al. 2008; Tolasa 2007; Yineger 2005). Lack of precision and standardization has been mentioned as a global drawback of the traditional healthcare system that needs to be rectified by putting in place global and national system that would recognize the role and contribution of traditional healers and also that ensures effective benefit sharing mechanism including intellectual property 
rights of the knowledge holders.

\subsection{Threats to medicinal plants and potential solutions}

The most serious threats to medicinal plants in the study area were agricultural land expansion, deforestation, over exploitation and land degradation, unsustainable fuel wood and charcoal production and overgrazing. Similar threatening factors have been reported from different regions within Ethiopia (Ashagre et al. 2016; Lulekal et al. 2008). This unregulated agricultural expansion resulted from high population growth and lack of land use policy in the Country. With the aim of increasing agricultural productivity, forest lands and grasslands have been converted into farmlands causing loss of local biodiversity including medicinal plants. Increasing agricultural productivity should not be at the expense of forest and grassland biodiversity and associated ecosystem services. Agricultural intensification should be considered as the only option to increase productivity using all technological inputs and human technical expertise. The other threatening factor was overexploitation of medicinal and other plants for timber, fuelwood and construction materials. Increasing energy availability to inhabitants in local towns and promoting plantation forestry to minimize negative impacts on natural forest and woodland ecosystems was noted as critical actions that should be taken as soon as possible. Some of the medicinal plants perceived by local communities as being threatened such as Millettia ferruginea, Urtica simensis, Solanecio gigas and Maytenus addat were also included in the IUCN Red lists. This could be one practical example of the complementary nature of indigenous and scientific knowledge that we need to make use of for the conservation and sustainable use of medicinal plants.

It was recommended that there is high need to conserve medicinal plants and their ecosystems in Nagelle Arsi District and other parts of the Country. Both regional and federal governments should give priority to conservation of these precious resources using both $i n$-situ and ex-situ conservation methods. Ethiopia has good environmental and biodiversity domestic legislations. However, law enforcement remains a practical challenge. Therefore, empowering institutions by both human and financial resources is critical to ensure sustainable utilization of medicinal plants in the Country. There should be strong regulation on production and sale of firewood. Furthermore, putting in place a functional system that would protect intellectual property rights of the traditional healers and also ensures their benefit sharing is important and timely. Technical support and capacity development of traditional healers for safe handling of medicinal plants and and their medicine were identified as important interventions. Bioprospecting on most commonly used medicinal species and establishing pharmacological industries was identified as one area of priority to promote conservation and sustainable use of medicinal plants in Ethiopia. Protection of intellectual property rights, capacity development and participatory bioprospecting researches were identified as important measures that would promote sustainable use of the rich medicinal plants in the study area and beyond.

\section{Conclusion}

The findings of this study revealed that Nagelle Arsi District was endowed with several medicinal plant species used for treating human and livestock ailments. Diverse medicinal plants were used for treating different diseases. Human ailments such as stomach discomfort and internal parasites, cough, fever, diarrhea, malaria, hemorrhoids, tapeworm, blood pressure, liver, kidney, toothache, tonsillitis, wound, cancer, headache, diabetes, prostate gland problem, asthma (respiratory complication), and many others were treated using indigenous knowledge of the local communities.

Local communities did prefer to use traditional medicines for their primary health care because of the fact that these remedies were available easily and also cheaper than the modern medicine. As leaves, roots and barks are the most frequently used plant parts for the preparation of remedies; there is a serious concern over the sustainable use of these medicinal plants. There is a need for conservation of these plants and public awareness raising with focus on threats to natural resources in general and medicinal plants in particular.

Although remedies were prescribed and given based on age, gender and pregnancy status, the knowledge gap on the right and effective dosage remained a serious concern calling for close follow up and support from the health sector and also from other related Institutions. The major threats to medicinal plants in the study area were anthropogenic factors such as agricultural land expansion, deforestation, over exploitation and land degradation, fuel wood and charcoal production and overgrazing. Conservation of medicinal plants using both in-situ and exsitu methods, rehabilitation of degraded ecosystems, sustainable use of natural resources and market linkages for potential medicinal plant products were recommended as a result of this study.

\section{Acknowledgements}

We would like to thank Ethiopian Biodiversity Institute (EBI) for both technical and financial support. We highly appreciate and thank Nagelle Arsi District communities and administration for their support during data collection. Special thanks to the informants who shared with us their knowledge on medicinal plants and also for their warm hospitality. We also thank Ethiopian National Herbarium staff members of Addis Ababa University for their help 
in facilitating plant specimen identification.

\section{References}

Abdela G,., Sultan, M. \& Amano, T. (2018), "Ethnobotanical Study of Medicinal Plants in Heban Arsi District, Oromia, South Eastern Ethiopia", Advances in Life Science and Technology 68, 27-45.

Asfaw, Z. \& Nigatu, A. (1995), "Homegardens in Ethiopia: Characteristics and Plant Diversity", SINET:Ethiop. J.Sci. 18(2), 235-266.

Ashagre, M., Kelbessa, E. \& Dalle, G.. (2016), "Ethnobotanical study of medicinal plants in Guji Agro-pastoralists, Blue Hora District of Borana Zone, Oromia Region, Ethiopia” Journal of Medicinal Plants Studies 4(2), 170184.

Awas, T. \& Demissew, S. (2009), "Ethnobotanical study of medicinal plants in Kafficho people, south western Ethiopia", Proceeding of the 16 international conference of Ethiopian studies, 711-726. Trondheim. Norway.

Awas, T. (2007), "Plant Diversity in Western Ethiopia: Ecology, Ethnobotany and Conservation", PhD Dissertation, Faculty of Mathematics and Natural Sciences, University of Oslo, Norway.

Aziz, M.A., Khan, A.H., Adnan, M. \& Ullah, H. (2018), “Traditional uses of medicinal plants used by Indigenous communities for veterinary practices at Bajaur Agency, Pakistan", J.EthnobiolEthnomed. 14:11. DOI 10.1186/s13002-018-0212-0.

Balemie, K, Kelbessa, E. \&, Asfaw, Z. (2004), "Indigenous medicinal plant utilization, management and threats in Fentalle area, Eastern Shewa. Ethiopia”, Ethiop. J. Biol. Sci., 3(1), 37-58.

Balick, M.J. \& Cox P.A.R. (1996), "Plants, people and culture. The science of Ethnobotany", Scientific American Library, New York, USA.

Cotton, C.M. (1996), "Ethnobotany: Principles and applications", John Wiley and Sons Ltd., Chichester, New York, pp.399.

Dalle, G.. (2015), "Floristic Composition, Populations Structure and Conservation Status of Woody Species in Shashemenne-Munessa Natural Forest, Ethiopia", Ethiopian Journal of Biodiversity 1(1), 21-44.

Demissew, S. \& Friis, I. (2009), Natural vegetation of the flora area", In: Flora Ethiopia and Eritrea volume 8. Pp. 27-32, (Hedberg I, Friis I and Person E.eds). Addis Ababa, Ethiopia and Uppsala, Sweden.

Gebrehiwot, M. (2010), "An Ethnobotanical study of medicinal plants in Seru Woreda, Arsi Zone of Oromia Region, Ethiopia", M.Sc. Thesis. Addis Ababa, Ethiopia.

Gemedo-Dalle, T., Maass, B. \& Isselstein, J. (2005), "Plant biodiversity and ethnobotany of Borana pastoralists in southern Oromia, Ethiopia", Journal of Economic Botany, 59 (1), 43-65.

Giday, M, Asfaw, Z., Elmqvist, T. \& Woldu, Z. (2003). "An ethnobotanical study of medicinal plants used by Zay people in Ethiopia", J Ethno Pharmacol. 85(1): 43-52.

Giday, M. (1999), “An Ethnobotanical study of Medicinal Plants Used by Zay People in Ethiopia”, MSc Thesis, Uppsala, Sweden.

Issa T.O., Mohamed, Y.S., Yagi, S., Ahmed, R.H., Najeeb, T.M., Makhawi, A.M. \& Khider, T.O. (2018), "Ethnobotanical investigation on medicinal plants in Algoz area (South Kordofan), Sudan", J Ethnobiol Ethnomed, 14:31.

Kidane L., Gebremedhin, G. \& Beyene, T. (2018), "Ethnobotanical study of medicinal plants in Ganta Afeshum District, Eastern Zone of Tigray, Northern Ethiopia", J Ethnobiol Ethnomed., 14:64.

Leonti, M., Vibrans, H, Sticher, O. \& Heinrich, M. (2001), "Ethnopharmacology of the populace, Mexico: an evaluation", J. Pharm. Pharmacol., 53: 1653-1669.

Lulekal, E., Asfaw, Z., Kelbessa, E. \& Van Damme, P. (2013), "Ethnomedicinal study of plants used for human ailments in Ankober District, North Shewa Zone,Amhara Region, Ethiopia", J Ethnobiol Ethnomed., 9:63.

Lulekal, E., Kelbessa, E., Bekele, T. \& Yineger, H. (2008), “An ethnobotanical study of medicinal plants in Mana Angetu District, southeastern Ethiopia”. J Ethnobiol Ethnomed., 4:10.

Martin, G.J. (1995), "Ethnobotany: A Methods Manual", London: Chapman and Hall, London, 267 pp.

Teklehaymanot, T., Giday, M., Medhin, G. \& Mekonnen, Y. (2007), "Knowledge and use of medicinal plants by people around DebreLibanos monastery in Ethiopia”, J Ethno Pharmacol.,111 (2), 271-283.

Tolasa, E. (2007), "Use and conservation of traditional medicinal plants by indigenous people in Gimbi woreda, western wellega Ethiopia", MSc.Thesis. Addis Ababa University, Addis Ababa.

Wendimu, T., Asfaw, Z. \& Kelbessa, E. (2007), "Ethnobotanical study of medicinal plants around Dheeraa town, Arsi Zone, Ethiopia”, J Ethno Pharmacol., 112 (1), 152-61.

Yineger, H. (2005), "A study of Ethno botany of Medicinal plants and Floristic Composition of the Dry Afromontane Forest at Bale Mountains National Park", MSc Thesis, Addis Ababa University, Ethiopia. 


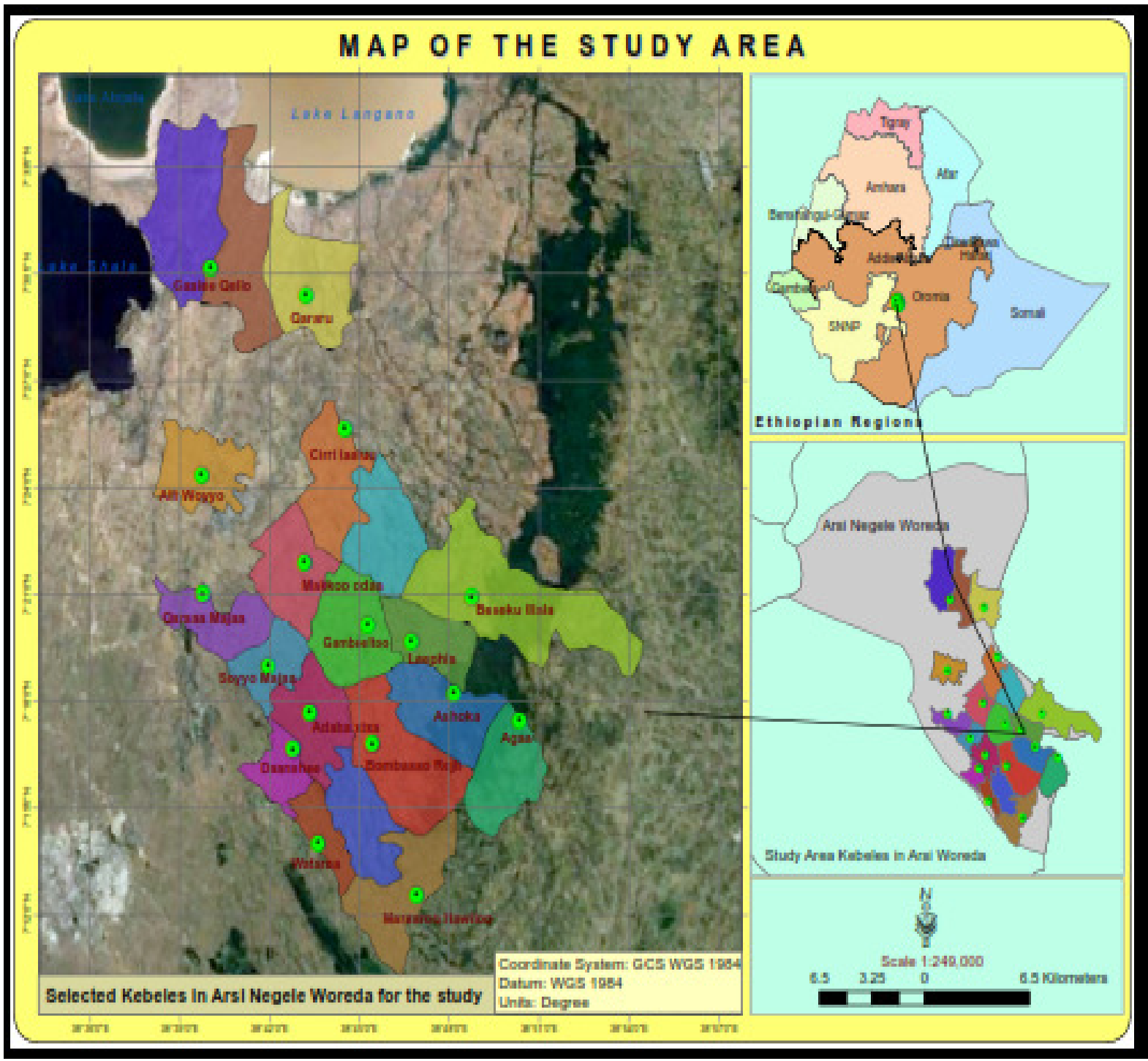

Figure1. Map of Ethiopia showing regional states and the study area

Table 1. Plant parts used for the treatment of human and livestock diseases in Nagelle Arsi District, Oromia, Ethiopia

\begin{tabular}{lll}
\hline $\begin{array}{l}\text { Plant } \\
\text { parts }\end{array}$ & $\begin{array}{l}\text { No. of } \\
\text { medicinal plants }\end{array}$ & $\mathbf{\%}$ \\
\hline Leaves & 70 & 46.66 \\
Roots & 26 & 25.49 \\
Barks & 23 & 15.33 \\
Seeds & 5 & 3.33 \\
Flowers & 3 & 2.00 \\
Sap & 1 & 1.00 \\
Bulbs & 1 & 1.00 \\
Fruits & 6 & 4.19 \\
Stems & 1 & 1.00 \\
\hline Total & 150 & 100 \\
\hline
\end{tabular}


Table 2. Major human disease treated with remedies prepared from medicinal plants in Nagelle Arsi District, Oromia, Ethiopia.

\begin{tabular}{ll}
\hline Types of diseases & No. of medicinal plants used \\
\hline Internal parasite & 14 \\
Malaria & 15 \\
Cough & 6 \\
Cancer & 4 \\
Blood pressure & 2 \\
Hemorrhoids & 6 \\
Liver & 5 \\
Diabetes & 2 \\
Diarrhea & 6 \\
Tuberculosis & 3 \\
\hline
\end{tabular}

Table 3. Major livestock disease treated with remedies prepared from medicinal plants in Nagelle Arsi District, Oromia, Ethiopia.

\begin{tabular}{ll}
\hline Disease & No. of medicinal plants used \\
\hline Anthrax & 25 \\
Black leg & 7 \\
Sudden sickness & 5 \\
Diarrhea & 8 \\
Skin disease & 4 \\
Wound & 5 \\
Cough & 4 \\
Mastitis & 1 \\
Internal parasites & 10 \\
Bone deafening & 2 \\
Eye disease & 1 \\
Hemorrhagic Septicemia & 9 \\
\hline
\end{tabular}

Table 4. Methods of traditional medicine preparations in Nagelle Arsi District, Oromia, Ethiopia.

\begin{tabular}{lll}
\hline Method & Total No. preparations & \% \\
\hline Crushing \& boiling & 73 & 43.45 \\
Powdering form & 42 & 25.00 \\
Chewing & 10 & 5.95 \\
Squeezing & 14 & 8.33 \\
Smoking & 8 & 4.76 \\
Washing & 11 & 6.54 \\
Rubbing & 7 & 4.19 \\
Cream & 3 & 1.78 \\
\hline Total & 168 & 100 \\
\hline
\end{tabular}

Table 5. Preference ranking of medicinal plants used to treat human and livestock disease in Nagelle Arsi District, Oromia, Ethiopia.

\begin{tabular}{|c|c|c|c|c|c|c|c|c|c|c|}
\hline \multirow[b]{2}{*}{ List of medicinal plants } & \multicolumn{10}{|c|}{ Respondent } \\
\hline & $\mathbf{R}_{1}$ & $\mathbf{R}_{2}$ & $\mathbf{R}_{3}$ & $\mathbf{R}_{4}$ & $\mathbf{R}_{5}$ & $\mathbf{R}_{6}$ & $\mathbf{R}_{7}$ & $\mathbf{R}_{8}$ & Total & Rank \\
\hline Podocarpus falcatus & 5 & 3 & 6 & 5 & 7 & 7 & 6 & 5 & 44 & 3 \\
\hline Croton macrostachyus & 6 & 5 & 7 & 6 & 5 & 6 & 5 & 5 & 45 & 2 \\
\hline Hagenia abyssinica & 3 & 4 & 4 & 3 & 5 & 3 & 2 & 1 & 25 & 4 \\
\hline Maesa lanceolata & 4 & 2 & 3 & 2 & 2 & 2 & 4 & 4 & 23 & 5 \\
\hline Syzgium guineense & 2 & 4 & 1 & 4 & 3 & 3 & 1 & 3 & 21 & 6 \\
\hline Shifleria abyssinica & 1 & 5 & 2 & 1 & 1 & 1 & 3 & 2 & 16 & 7 \\
\hline Vernonia amygdalina & 7 & 7 & 6 & 6 & 6 & 5 & 7 & 6 & 50 & 1 \\
\hline
\end{tabular}


Table 6. Direct matrix ranking by respondents for six plant species and five major uses in Nagelle Arsi District, Oromia, Ethiopia.

\begin{tabular}{|c|c|c|c|c|c|c|c|}
\hline \multirow[t]{2}{*}{ List of medicinal plants } & \multicolumn{5}{|c|}{ Use categories } & \multirow[t]{2}{*}{ Total } & \multirow[t]{2}{*}{ Rank } \\
\hline & Medicine & Food & $\begin{array}{l}\text { Fuel } \\
\text { wood }\end{array}$ & Forage & $\begin{array}{l}\text { Const- } \\
\text { ruction }\end{array}$ & & \\
\hline Allophylus abyssinicus & 6 & 5 & 3 & 4 & 2 & 20 & 2 \\
\hline Celtis africana & 4 & 0 & 5 & 5 & 6 & 20 & 2 \\
\hline Cordia africana & 2 & 3 & 5 & 2 & 6 & 18 & 4 \\
\hline Erythrina abyssinica & 6 & 0 & 3 & 5 & 2 & 16 & 5 \\
\hline Prunus africana & 6 & 0 & 5 & 2 & 6 & 19 & 3 \\
\hline Syzgium guineense & 6 & 5 & 5 & 3 & 4 & 23 & 1 \\
\hline
\end{tabular}

Table 7. Paired comparisons for five marketable medicinal plants in Nagelle Arsi District, Oromia, Ethiopia

\begin{tabular}{lllllllllll}
\hline & \multicolumn{3}{l}{ Respondent } & \multicolumn{1}{c}{ Total } & \multicolumn{3}{c}{ Rank } \\
List of medicinal plants & $\mathbf{R}_{\mathbf{1}}$ & $\mathbf{R}_{\mathbf{2}}$ & $\mathbf{R}_{\mathbf{3}}$ & $\mathbf{R}_{\mathbf{4}}$ & $\mathbf{R}_{\mathbf{5}}$ & $\mathbf{R}_{\mathbf{6}}$ & $\mathbf{R}_{\mathbf{7}}$ & $\mathbf{R}_{\mathbf{8}}$ & & 5 \\
\hline Allophylus abyssinicus & 3 & 3 & 2 & 2 & 1 & 2 & 1 & 3 & 17 & 4 \\
Balanites aegyptica & 3 & 3 & 4 & 2 & 3 & 4 & 3 & 2 & 24 & 3 \\
Carissa spinarum & 4 & 3 & 4 & 3 & 2 & 3 & 4 & 2 & 25 & 2 \\
Syzgium guineense & 4 & 4 & 4 & 3 & 4 & 4 & 3 & 4 & 30 & 1 \\
Ximenia americana & 4 & 4 & 4 & 4 & 4 & 4 & 4 & 4 & 32 & 1 \\
\hline
\end{tabular}

Table 8. Informant consensus of most popular medicinal plants in Nagelle Arsi District, Oromia, Ethiopia

\begin{tabular}{|c|c|c|c|}
\hline Scientific Name & No. of informants & $\%$ & Rank \\
\hline Ocimum lamiifolium & 19 & 11 & 2 \\
\hline Moringa stenopetala & 13 & 9 & 6 \\
\hline Croton macrostachyus & 17 & 12 & 4 \\
\hline Artemisia rehan & 15 & 10 & 5 \\
\hline Olea europea subsp.cuspidata & 11 & 8 & 8 \\
\hline Ruta chalepensis & 20 & 14 & 1 \\
\hline Vernonia amygdalina & 18 & 13 & 3 \\
\hline Hagenia abyssinica & 12 & 8 & 7 \\
\hline Withania somenifera & 10 & 7 & 9 \\
\hline Prunus africana & 11 & 8 & 8 \\
\hline
\end{tabular}

Table 9. Most common medicinal plants sold in the local market area in Nagelle Arsi, Oromia, Ethiopia

\begin{tabular}{lll}
\hline Scientific name & Unit of measure & Price (Ethiopian Birr) \\
\hline Brassica olearcea & Cup of coffee & 10 \\
Coriandrum sativum & Cup of coffee & 7 \\
Hagenia abyssinica & $\mathrm{Kg}$ & 20 \\
Lippia adoensis & Tie bundles & 5 \\
Moringa stenopetala & $\mathrm{Kg}$ & 150 \\
Olea europea subsp.cuspidata & Tie bundles & 200 \\
Ricinus communis & Cup of coffee & 10 \\
Ruta chalepensis & Tie bundles & 5 \\
Withania somenifera & Tie bundles & 10 \\
\hline
\end{tabular}

Table10. Major threats to medicinal plants inNagelle Arsi District, Oromia, Ethiopia.

\begin{tabular}{|c|c|c|c|c|c|c|c|c|c|c|c|c|c|}
\hline \multirow[t]{2}{*}{ Threats } & \multicolumn{10}{|c|}{ Respondent } & \multirow[t]{2}{*}{$T^{*}$} & \multirow[t]{2}{*}{$\mathbf{R}^{*}$} & \multirow[t]{2}{*}{$\%$} \\
\hline & $\mathbf{R}_{1}$ & $\mathbf{R}_{\mathbf{2}}$ & $\mathbf{R}_{\mathbf{3}}$ & $\mathbf{R}_{\mathbf{4}}$ & $\mathbf{R}_{5}$ & $\mathbf{R}_{6}$ & $\mathbf{R}_{7}$ & $\mathbf{R}_{8}$ & $\mathbf{R 9}_{\mathbf{9}}$ & $\mathbf{R}_{\mathbf{1 0}}$ & & & \\
\hline Agricultural Expansion & 5 & 4 & 5 & 5 & 5 & 4 & 4 & 4 & 5 & 4 & 45 & 2 & 20.36 \\
\hline Deforestation & 6 & 6 & 6 & 6 & 5 & 6 & 6 & 5 & 5 & 5 & 56 & 1 & 25.33 \\
\hline Fuelwood and Charcoal & 3 & 5 & 4 & 4 & 3 & 3 & 4 & 5 & 5 & 4 & 40 & 3 & 18.09 \\
\hline Over exploitation & 4 & 4 & 5 & 4 & 3 & 3 & 4 & 4 & 3 & 5 & 39 & 4 & 17.64 \\
\hline Overgrazing & 2 & 2 & 3 & 2 & 3 & 2 & 2 & 3 & 3 & 2 & 24 & 5 & 10.85 \\
\hline Drought & 2 & 3 & 2 & 2 & 1 & 2 & 1 & 1 & 2 & 1 & 17 & 6 & 7.69 \\
\hline
\end{tabular}

$\mathrm{T}^{*}=$ Total and $\mathrm{R}^{*}=$ Rank and $\mathrm{R} 1$ to $\mathrm{R} 10$ are respondents 1 to 10 
Appendix1. List of medicinal plants in Nagelle Arsi district, Oromia, Ethiopia.

\begin{tabular}{|c|c|c|c|c|c|}
\hline No. & Plant Name & Family Name & $\begin{array}{l}\text { Local Name } \\
\text { (Afaan Oromoo.) }\end{array}$ & Code & $\begin{array}{l}\text { Growth } \\
\text { Habit }\end{array}$ \\
\hline 1 & Acacia abyssinica Hochst.ex Benth. & FABACEAE & Laaftoo & MBGH-084 & $\mathrm{T}$ \\
\hline 2 & Achyranthes aspera L. & AMARANTHACEAE & Darguu & MBGH-026 & $\mathrm{H}$ \\
\hline 3 & $\begin{array}{lll}\text { Acokanthera } & \text { schimperi } & \text { (A.DC) } \\
\text { Schweinf. } & & \\
\end{array}$ & APOCYNACEAE & Qaraaruu & MBGH-070 & $\mathrm{S}$ \\
\hline 4 & $\begin{array}{lll}\begin{array}{l}\text { Podocarpus } \\
\text { ex.mirb }\end{array} & \text { falcatus } & \text { (Thunb.)R.B } \\
\end{array}$ & PODOCARPACEAE & Birbissa & MBGH-005 & $\mathrm{T}$ \\
\hline 5 & Agave sisalina perrine perrine ex. Engl. & AGAVACEAE & Qachaa & MBGH-064 & $\mathrm{H}$ \\
\hline 6 & $\begin{array}{l}\text { Ajuga integrifolia Buch.-Ham. ex D. } \\
\text { Don }\end{array}$ & LAMIACEAE & Harmmaguusaa & MBGH-103 & $\mathrm{H}$ \\
\hline 7 & Allium sativum L. & ALLIACEAE & Qullubbi adii & MBGH-105 & $\mathrm{H}$ \\
\hline 8 & $\begin{array}{l}\text { Albizia gummifera (J.F.Gmel.) } \\
\text { C.A.Sm.var }\end{array}$ & FABACEAE & Qarcacee & MBGH-035 & $\mathrm{T}$ \\
\hline 9 & Allophylus abyssinicus Hochst.ex Benth. & SAPINDACEAE & Hirqamuu & MBGH-010 & $\mathrm{T}$ \\
\hline 10 & Aloe spp. & ALOACEAE & Hargiisa & MBGH-008 & $\mathrm{H}$ \\
\hline 11 & Amaranthus caudatus L. & AMARANTHACEAE & Urgoo harree & MBGH-027 & $\mathrm{H}$ \\
\hline 12 & Amaranthus spinosus L. & AMARANTHACEAE & Raafuu harre & MBGH-074 & $\mathrm{H}$ \\
\hline 13 & Apodytes dimidata E.Mey.ex .Arn & ICACINACEAE & Odaa baddaa & MBGH-038 & $\mathrm{T}$ \\
\hline 14 & Artemisia rehan Chiov. & ASTERACEAE & Ariitii & MBGH-080 & $\mathrm{H}$ \\
\hline 15 & Asparagus africanus Lam. & ASPARAGACEAE & Sariitii & MBGH-034 & $\mathrm{S}$ \\
\hline 16 & Balanites aegyptica (L.) Del.Dc. & BALANITACEAE & Badana & MBGH-055 & $\mathrm{T}$ \\
\hline 17 & Bersama abyssinica Fresen. & MELIANTHACEAE & Korqaa & MBGH-017 & $\mathrm{T}$ \\
\hline 18 & Brassica olearcea var. Capitata L. & BRACICACEAE & Danqalee & MBGH-037 & $\mathrm{H}$ \\
\hline 19 & Brucea antidysentrica J.F Miller & SIMAROUBACEAE & Ciirotaa & MBGH-023 & $\mathrm{T}$ \\
\hline 20 & Buddleja polystachya Fresen. & LOGINACEAE & Bulchanaa & MBGH-090 & $\mathrm{S}$ \\
\hline 21 & Calpurnia aurea (Ait.) Benth. & FABACEAE & Ceekataa & MBGH-013 & $\mathrm{S}$ \\
\hline 22 & Capparis tomentose Lam. & CAPPARIDACEAE & Hunxuxii & MBGH-095 & $\mathrm{L}$ \\
\hline 23 & Carissa spinarum L. & APOCYNACEAE & Agamsa & MBGH-040 & $\mathrm{S}$ \\
\hline 24 & Celtis africana Burm.f. & UIMACEAE & Amalaqaa & MBGH-002 & $\mathrm{T}$ \\
\hline 25 & Clematis simensis Fresen. & RANUNCULACEAE & Fitii & MBGH-046 & $\mathrm{C}$ \\
\hline 26 & $\begin{array}{lll}\text { Clerodendrum myricoides } & \text { (Hochst.) } \\
\text { R.Br.ex vatke } & & \\
\end{array}$ & VERBENACEAE & Marachissa & MBGH-048 & $\mathrm{S}$ \\
\hline 27 & Cordia africana Lam. & BORGINACEAE & Wodessa & MBGH-096 & $\mathrm{T}$ \\
\hline 28 & Coriandrum sativum L. & APIACEAE & Dimbelal & MBGH-105 & $\mathrm{H}$ \\
\hline 29 & Croton dichogomas $\mathrm{Pax}$ & EUPHORBIACEAE & Ulee foonii & MBGH-056 & $\mathrm{S}$ \\
\hline 30 & Croton macrostachyus Hochst. & EUPHORBIACEAE & Mokoniisa & MBGH-019 & $\mathrm{T}$ \\
\hline 31 & Cynoglosum lanceolatum Forssk. & BORGINACEAE & Maxxannee & MBGH-024 & $\mathrm{H}$ \\
\hline 32 & $\begin{array}{l}\text { Cyphostemma adenocalule ( Steud.ex } \\
\text { A.Rich) Desc.ex Wild \& Dr }\end{array}$ & VITACEAE & Gaalee & MBGH-057 & $\mathrm{C}$ \\
\hline 33 & Datura stramonium L. & SOLANACEAE & Banji & MBGH-069 & $\mathrm{H}$ \\
\hline 34 & Delonix elata (L.) & FABACEAE & Harangama & MBGH-104 & $\mathrm{T}$ \\
\hline 35 & Discopodium penninervum (Hochest.) & SOLANACEAE & Maraaroo & MBGH-083 & $\mathrm{S}$ \\
\hline 36 & Dovalis abyssinica (A.Rich.)Warb. & FLACOURTIACEAE & Dhangangoo & MBGH-094 & $\mathrm{S}$ \\
\hline 37 & Echinopes angustilobus S.moore & ASTERACEAE & Anishookalaa & MBGH-039 & $\mathrm{S}$ \\
\hline 38 & Ekebergia capensis Sparm & MILIACEAE & Oononnuu & MBGH-052 & $\mathrm{T}$ \\
\hline 39 & Embelia schimperi Vatke. & MYRSINACEAE & Qaanquu & MBGH-018 & $\mathrm{S}$ \\
\hline 40 & Erythrina abyssinica Lam.ex.Dc & FABACEAE & Woleenaa & MBGH-009 & $\mathrm{T}$ \\
\hline 41 & Euclea schimperi ( Dc) Dandy & EBENACEAE & Mi'eessa & MBGH-060 & $\mathrm{T}$ \\
\hline 42 & Euphorbia abyssinica Gmel & EUPHORBIACEAE & Adaamii & MBGH-082 & $\mathrm{T}$ \\
\hline 43 & Euphorbia depauperata & EUPHORBIACEAE & Gurii & MBGH-036 & $\mathrm{H}$ \\
\hline 44 & Ficus thonningii Blume & MORACEAE & Dambii & MBGH-031 & $\mathrm{T}$ \\
\hline 45 & Galneria saxifrage (Hochest.) Bridson & RUBIACEAE & Korolla & MBGH-088 & $\mathrm{S}$ \\
\hline 46 & Grewia ferruginea Hochst.Ex A. Rich & TELIACEAE & Dhoqona & MBGH-071 & $\mathrm{S}$ \\
\hline 47 & Hagenia abyssinica (Bruce)J.F.Gmelin & ROSACEAE & Heexoo & MBGH-051 & $\mathrm{T}$ \\
\hline 48 & Hypericum quartinianum A.Rich. & HYPERICACEAE & Garanbaa & MBGH-081 & $\mathrm{S}$ \\
\hline 49 & $\begin{array}{l}\text { Justicia schimperiana (Hochst.ex Nees) } \\
\text { T.Anders. }\end{array}$ & ACANTHACEAE & Dhummuugaa & MBGH-066 & $\mathrm{S}$ \\
\hline 50 & Juniperus procera Hochst. ex Endl. & CUPPRESSACEAE & Hidheessa & MBGH-102 & $\mathrm{T}$ \\
\hline 51 & Kalanchoe petitiana A.Rich. & CRASSULACEAE & Hancuuraa & MBGH-016 & $\mathrm{H}$ \\
\hline 52 & Lippia adoensis L. & VERBENACEAE & Sokorruu & MBGH-063 & $\mathrm{S}$ \\
\hline 53 & Maesa Lanceolata Forssk. & MYRSINACEAE & Abayyi & MBGH-011 & $\mathrm{T}$ \\
\hline
\end{tabular}




\begin{tabular}{|c|c|c|c|c|c|}
\hline No. & Plant Name & Family Name & $\begin{array}{l}\text { Local Name } \\
\text { (Afaan Oromoo.) }\end{array}$ & Code & $\begin{array}{l}\text { Growth } \\
\text { Habit }\end{array}$ \\
\hline 54 & Malva verticillatum L. & MALVACEAE & & MBGH-075 & $\mathrm{H}$ \\
\hline 55 & Maytenus addat (Looes.) & CELASTERACEAE & Kombolcha & MBGH-073 & $\mathrm{T}$ \\
\hline 56 & Maytenus arbutifolia (A.Rich.) Wilczek & CELASTERACEAE & Kombolcha & MBGH-077 & $\mathrm{T}$ \\
\hline 57 & Milletia ferruginea (Hochst.) Bakk. & FABACEAE & Dadatuu/ Birbiraa & MBGH-042 & $\mathrm{T}$ \\
\hline 58 & Mimusops kummel A.DC. & SAPOTACEAE & Olaati & MBGH-059 & $\mathrm{T}$ \\
\hline 59 & Moringa stenopetala (Bok.f.) cuf & MORINGACEAE & Moringaa & MBGH-100 & $\mathrm{T}$ \\
\hline 60 & Myrica salcifolia A.Rich. & MYRICACEAE & Qamoo & MBGH-102 & $\mathrm{T}$ \\
\hline 61 & Myrsine africana $\mathrm{L}$ & MYRSINACEAE & Xeexee/Abeyee & MBGH-095 & $\mathrm{S}$ \\
\hline 62 & Myrsine melanophlous (L.) R.Br. & MYRSINACEAE & Tuulla & MBGH-020 & $\mathrm{S}$ \\
\hline 63 & Nuxia congesta R.Br. ex Fresen & BUDDLEIACEAE & Biixannaa & MBGH-078 & $\mathrm{T}$ \\
\hline 64 & Ocimum basilicum L. & LAMIACEAE & Bassobilaa & MBGH-028 & $\mathrm{S}$ \\
\hline 65 & Ocimum gratisimum $\mathrm{L}$. & LAMIACEAE & Cabbicha & MBGH-098 & $\mathrm{S}$ \\
\hline 66 & Ocimum lamiifolium Hochst.ex Benth. & LAMIACEAE & Qoricha michii & MBGH-012 & $\mathrm{S}$ \\
\hline 67 & Ocimum urticifolium Roth. & LAMIACEAE & Cabbicha & MBGH-085 & $\mathrm{S}$ \\
\hline 68 & Olea europea subsp.cuspidata L. & OLEACEAE & Ejersa & MBGH-008 & $\mathrm{T}$ \\
\hline 69 & Olinia rochetiana A.Juss. & OLINIACEAE & Gunaa & MBGH-101 & $\mathrm{T}$ \\
\hline 70 & Opuntia ficus-indica (L.) Miller. & CACTACEAE & Qulqualii & MBGH-061 & $\mathrm{S}$ \\
\hline 71 & Plectranthus marrubatus & LAMIACEAE & $\begin{array}{l}\text { Qoricha } \\
\text { michii/Damakasee }\end{array}$ & MBGH-072 & $\mathrm{H}$ \\
\hline 72 & Phytolacca dodecandra L Her. & PHYTOLACCACEAE & Handoodee & MBGH-030 & $\mathrm{L}$ \\
\hline 73 & Prunus africana (Hook.f)Kalkm & ROSACEAE & Sukkee & MBGH-001 & $\mathrm{T}$ \\
\hline 74 & Psydrax schimperiana (A.Rich.) Bridson & RUBIACEAE & Gaalloo & MBGH-050 & $\mathrm{T}$ \\
\hline 75 & Plantago lanceolata L. & PLANTAGINACEAE & Gorxobii & MBGH-106 & $\mathrm{H}$ \\
\hline 76 & Rhus tenuinervis Engl. & ANACARDIACEAE & Qolasaa & MBGH-097 & $\mathrm{S}$ \\
\hline 77 & Ricinus communis L. & EUPHORBIACEAE & Qoboo & MBGH-029 & $\mathrm{S}$ \\
\hline 78 & Rubus steudneri Schweinf. & RUBIACEAE & Goraa & MBGH-089 & $\mathrm{S}$ \\
\hline 79 & Rumex abyssinica Jacq. & POLYGONACEAE & & MBGH-067 & $\mathrm{H}$ \\
\hline 80 & Rumex nepalensis Spreng. & POLYGONACEAE & Shabbee & MBGH-045 & $\mathrm{H}$ \\
\hline 81 & Ruta chalepensis L. & RUTACEAE & Xenadam & MBGH-025 & $\mathrm{H}$ \\
\hline 82 & Saliva nilotica Juss.ex Jacq. & LAMIACEAE & Hulegebi & MBGH-101 & $\mathrm{H}$ \\
\hline 83 & Senna septromolisis & FABACEAE & Ajaawaa & MBGH-047 & $\mathrm{S}$ \\
\hline 84 & Shiffleria abyssinica & SAPOTACEAE & Gatamee & MBGH-003 & $\mathrm{T}$ \\
\hline 85 & Sida rhombifolia L. & MALVACEAE & Chifirigi & MBGH-033 & $\mathrm{H}$ \\
\hline 86 & Senecio gigas Vatke & ASTERACEAE & Agadena & MBGH-022 & $\mathrm{H}$ \\
\hline 87 & Solansio myriocephalus Sch. Bip. & ASTERACEAE & & MBGH-091 & $\mathrm{S}$ \\
\hline 88 & Solanum anguivi $\mathrm{L}$. & SOLANACEAE & & MBGH-107 & $\mathrm{S}$ \\
\hline 89 & Solanum incanum L. & SOLANACEAE & Hiddii & MBGH-044 & $\mathrm{S}$ \\
\hline 90 & Solanum marginatum L.f. & SOLANACEAE & Hiddii Oromo & MBGH-043 & $\mathrm{S}$ \\
\hline 91 & Spilanthes uliginosa SW. & ASTERACEAE & & MBGH-032 & $\mathrm{H}$ \\
\hline 92 & $\begin{array}{l}\text { Stephania abyssinica (Dillon \& A.Rich.). } \\
\text { Walp. }\end{array}$ & MENISPERMACEAE & Kalaalaa & MBGH-015 & $\mathrm{C}$ \\
\hline 93 & Syzgium guineense (willd.)Dc. & MYRTACEAE & Baddeessaa & MBGH-006 & $\mathrm{T}$ \\
\hline 94 & Teclea simplicifolia (Engl.) Verdoorn. & RUTACEAE & Hadheessaa & MBGH-007 & $\mathrm{T}$ \\
\hline 95 & Teclea nobils Del. & RUTACEAE & Hadheessaa & MBGH-108 & $\mathrm{T}$ \\
\hline 96 & Urtica simensis Steudel & URTICACEAE & Doobii & MBGH-014 & $\mathrm{S}$ \\
\hline 97 & Urera hypselodendron (A.Rich) & URTICACEAE & Haliilaa & MBGH-053 & $\mathrm{S}$ \\
\hline 98 & Vernonia amygdalina Del. & ASTERACEAE & Ebicha & MBGH-004 & $\mathrm{S}$ \\
\hline 99 & Vernonia urticifolia A.Rich & ASTERACEAE & Reejii & MBGH-099 & $\mathrm{S}$ \\
\hline 100 & Withania somenifera (L.) Dunal in DC. & SOLANACEAE & Unsoo & MBGH-054 & $\mathrm{S}$ \\
\hline 101 & Ximenia americana $\mathrm{L}$. & OLEACEAE & Hudhaa & MBGH-068 & $\mathrm{S}$ \\
\hline 102 & Ziziphus spina-christi (L.) Desf. & RHAMNACEAE & Qurquraa & MBGH-093 & $\mathrm{T}$ \\
\hline
\end{tabular}


Appendix2. Medicinal plants used for treating human and livestock diseases in Nagelle Arsi District, Oromia, Ethiopia. PU: Parts used, L: Leaves, R: Root, B: Bark, Fr: Fruit, F: Flower, Hu: Human, Ls: Livestock

\begin{tabular}{|c|c|c|c|c|c|}
\hline Scientific & $\mathbf{P U}$ & Use & Diseases & Mode of preparation & $\begin{array}{l}\text { Route of } \\
\text { Add. }\end{array}$ \\
\hline $\begin{array}{l}\text { Acacia abyssinica } \\
\text { Hochst.ex Benth. }\end{array}$ & $\mathrm{R}$ & $\mathrm{Hu}$ & Swelling & $\begin{array}{l}\text { Crushed the root part and put on the } \\
\text { swelling part of the body }\end{array}$ & Dermal \\
\hline \multirow[b]{3}{*}{ Achyranthes aspera L. } & $\mathrm{R}$ & $\mathrm{Hu}$ & Malaria, TB & $\begin{array}{l}\text { Crushed the root part and mixed with } \\
\text { water } 1 \text { cup of coffee for } 2 \text { days }\end{array}$ & Oral \\
\hline & $\mathrm{R}$ & $\mathrm{Hu}$ & Abortion & $\begin{array}{l}\text { Crushed the root } \& \text { mixed with watet, } \\
1 \text { cup of coffee }\end{array}$ & Oral \\
\hline & $\mathrm{R}$ & Ls & Internal parasite & $\begin{array}{l}\text { Crushed the root part and mixed with } \\
\text { salt } 1 \text { litter for } 3 \text { days }\end{array}$ & Oral \\
\hline \multirow[b]{3}{*}{$\begin{array}{l}\text { Acokanthera schimperi } \\
\text { (A.DC) Schweinf. }\end{array}$} & $\mathrm{L}$ & $\mathrm{Hu}$ & Cancer & $\begin{array}{l}\text { Crushed the leaves and mix with } \\
\text { water for } 5 \text { days } 1 \text { cup of tea }\end{array}$ & Oral \\
\hline & $\mathrm{L}$ & $\mathrm{Hu}$ & Tooth ache & $\begin{array}{l}\text { Crushed the leaves \& ponded, then } \\
\text { chewing }\end{array}$ & Oral \\
\hline & L\& R & Ls & Anthrax & $\begin{array}{l}\text { Crushed the leaves and root part \& } \\
\text { mixed with water for } 7 \text { days } 1 \text { litter }\end{array}$ & Oral \\
\hline \multirow[b]{3}{*}{$\begin{array}{l}\text { Podocarpus falcatus } \\
\text { (Thunb.) R.B ex..mirb }\end{array}$} & $\mathrm{B}$ & $\mathrm{Hu}$ & $\begin{array}{l}\text { Hemorrhoids } \\
\text { Cancer } \\
\text { TB }\end{array}$ & $\begin{array}{l}\text { Crushed the leaves \& mix with water } \\
\text { for } 7 \text { days }\end{array}$ & Dermal \\
\hline & $\mathrm{B}$ & Ls & Internal parasites & $\begin{array}{l}\text { Crushed the bark \& with water } 1 \text { litter } \\
\text { for } 3 \text { days }\end{array}$ & Oral \\
\hline & B & Ls & Anthrax & $\begin{array}{l}\text { Crushed the bark mix with water } \\
1 \text { litter for } 5 \text { days }\end{array}$ & Oral \\
\hline \multirow[b]{2}{*}{$\begin{array}{l}\text { Agave sisalina perrine ex. } \\
\text { Engl. }\end{array}$} & $\mathrm{L}$ & $\mathrm{Hu}$ & $\begin{array}{l}\text { Hemorrhoids, } \\
\text { cancer }\end{array}$ & $\begin{array}{l}\text { Crushed the leaves \& mixed with } \\
\text { water }\end{array}$ & Oral \\
\hline & $\mathrm{L}$ & Ls & Anthrax & $\begin{array}{l}\text { Crushed the leaves \& mixed with salt } \\
\text { for } 5 \text { days }\end{array}$ & Oral \\
\hline $\begin{array}{l}\text { Ajuga integrifolia } \text { Buch.- } \\
\text { Ham. ex D. Don }\end{array}$ & $\mathrm{R}$ & $\mathrm{Hu}$ & Internal parasites & $\begin{array}{l}\text { Crushed the root part \& mix with } \\
\text { water } 2 \text { tea spoon } 1 \text { day }\end{array}$ & Oral \\
\hline \multirow[b]{2}{*}{$\begin{array}{l}\text { Albizia gummifera } \\
\text { (J.F.Gmel.) C.A.Sm.var }\end{array}$} & L \& R & $\mathrm{Hu}$ & $\begin{array}{l}\text { Hemorrhoids, } \\
\text { Liver }\end{array}$ & $\begin{array}{l}\text { Crushed the leaves, roots \& mixed } \\
\text { with water } 1 / 2 \text { cup of tea }\end{array}$ & Oral \\
\hline & $\mathrm{L}$ & Ls & Anthrax & $\begin{array}{l}\text { Crushed the leaves, roots } \& \text { mixed } \\
\text { with water, 1lit for 3days }\end{array}$ & Oral \\
\hline \multirow[b]{2}{*}{ Allium sativum L. } & $\mathrm{BL}$ & $\mathrm{Hu}$ & Common cold & $\begin{array}{l}\text { The bulb boiled with milk \& honey } \\
\text { until the disease will cure } \\
\text { cure }\end{array}$ & Oral \\
\hline & $\mathrm{BL}$ & $\mathrm{Hu}$ & Malaria & The bulb boiled with honey for 7 days & Oral \\
\hline \multirow[b]{2}{*}{$\begin{array}{l}\text { Allophylus abyssinicus } \\
\text { (Hochest.) Radlk. }\end{array}$} & $\mathrm{B}$ & $\mathrm{Hu}$ & Diarrhea & $\begin{array}{l}\text { Crushed the bark part \& mix with } \\
\text { water } 1 / 2 \text { cup of coffee for } 1 \text { week }\end{array}$ & Oral \\
\hline & B & $\mathrm{Hu}$ & Wound & $\begin{array}{l}\text { Crushed the bark part \& mix with } \\
\text { butter, put on infected part of the skin }\end{array}$ & Dermal \\
\hline \multirow[b]{2}{*}{ Aloe spp. } & $\mathrm{L}$ & $\mathrm{Hu}$ & Diarrhoea & Boiled the leaf part, $1 / 2$ cup of coffee & Oral \\
\hline & $\mathrm{L}$ & Ls & Sudden sickness & $\begin{array}{l}\text { Crushed the leaves and take sap \& } \\
\text { mix with water, } 1 \text { lit. for } 1-2 \text { days }\end{array}$ & Oral \\
\hline Amaranthus caudatus L. & S \& L & $\mathrm{Hu}$ & Diarrhea & $\begin{array}{l}\text { Grind the seed or crushed the leaves } \\
\& \text { mixed with Allium s. }\end{array}$ & Oral \\
\hline \multirow{2}{*}{$\begin{array}{l}\text { Amaranthus spinosus } \mathrm{L} . \\
\text { Apodytes } \\
\text { E.Mey.ex .Arn }\end{array}$} & $\mathrm{S}$ & $\mathrm{Hu}$ & Diarrhea & Crushed the leaves $\&$ boil with water & Oral \\
\hline & $\mathrm{B}$ & $\mathrm{Hu}$ & $\begin{array}{l}\text { Stomach ache, } \\
\text { cough }\end{array}$ & $\begin{array}{l}\text { Crushed \& boild the bark part \& } \\
\text { mixed with milk }\end{array}$ & Oral \\
\hline Artemisia rehan Chiov. & $\mathrm{L}$ & $\mathrm{Hu}$ & Evil eye & Crushed the leaves, fumigate & Nasal \\
\hline \multirow[b]{2}{*}{$\begin{array}{l}\text { Asparagus africanus } \\
\text { Lam. }\end{array}$} & $\mathrm{R} \& \mathrm{~L}$ & $\mathrm{Hu}$ & $\mathrm{TB}$, cough, wound & $\begin{array}{l}\text { Crushed the root part \& mix with } \\
\text { water } 2 \text { tea spoon } 7 \text { day } \\
\text { Crushed the leaves and put on the } \\
\text { wound }\end{array}$ & $\begin{array}{l}\text { Oral } \\
\text { dermal }\end{array}$ \\
\hline & $\mathrm{R}$ & $\mathrm{L}$ & Anthrax, black leg & $\begin{array}{l}\text { Crushed the root part \& mix with } \\
\text { water } 1 \text { cup of tea } 5 \text { day }\end{array}$ & Oral \\
\hline $\begin{array}{l}\text { Balanites aegyptica (L.) } \\
\text { Del.Dc. }\end{array}$ & $\mathrm{L}$ & $\mathrm{Hu}$ & Malaria & $\begin{array}{l}\text { Crushed \& boiled the Leaves part } \& \\
\text { mix with water } 1 \text { cup of tea for } 5 \text { day }\end{array}$ & Oral \\
\hline
\end{tabular}




\begin{tabular}{|c|c|c|c|c|c|}
\hline Scientific & $\mathbf{P U}$ & Use & Diseases & Mode of preparation & $\begin{array}{l}\text { Route of } \\
\text { Add. }\end{array}$ \\
\hline & $\mathrm{L}$ & Ls & Anthrax & $\begin{array}{l}\text { Crushed the Leaves part \& mix with } \\
\text { water 1cup of tea } 7 \text { day }\end{array}$ & Oral \\
\hline $\begin{array}{l}\text { Bersama abyssinica } \\
\text { Fresen. }\end{array}$ & $\mathrm{B}$ & $\mathrm{Hu}$ & Cough & $\begin{array}{l}\text { Crushed the Leaves part \& mix with } \\
\text { water }\end{array}$ & Oral \\
\hline $\begin{array}{l}\text { Brassica olearcea var. } \\
\text { Capitata L. }\end{array}$ & $\mathrm{S}$ & $\mathrm{Hu}$ & $\begin{array}{l}\text { Amoeba, common } \\
\text { cold }\end{array}$ & $\begin{array}{l}\text { Grind the seed \& mix with water. 3tea } \\
\text { spoon } 2 \text { tims a day }\end{array}$ & Oral \\
\hline $\begin{array}{l}\text { Brucea antidysentrica J.F } \\
\text { Miller }\end{array}$ & $\mathrm{S}$ & $\mathrm{Hu}$ & Amoeba & Grind the seed \& mix with water. & Oral \\
\hline \multirow{2}{*}{$\begin{array}{l}\text { Buddleja polystachya } \\
\text { Fresen. }\end{array}$} & $\mathrm{L}$ & $\mathrm{Hu}$ & Wound & $\begin{array}{l}\text { Crushed the leaves \& put on the } \\
\text { wound }\end{array}$ & Dermal \\
\hline & $\mathrm{L}$ & $\mathrm{Hu}$ & Tonsillitis & Crushed the leaves & Oral \\
\hline \multirow[b]{2}{*}{$\begin{array}{l}\text { Calpurnia aurea (Ait.) } \\
\text { Benth. }\end{array}$} & $\mathrm{L}$ & $\mathrm{Hu}$ & $\begin{array}{l}\text { Malaria, Common } \\
\text { cold, }\end{array}$ & $\begin{array}{l}\text { Crushed the leaves \& mixed with } \\
\text { water }\end{array}$ & Oral \\
\hline & R\& L & Ls & Internal parasites & $\begin{array}{l}\text { Crushed the leaves, root and mix with } \\
\text { salt 3litters for ox }\end{array}$ & Oral \\
\hline \multirow{4}{*}{ Capparis tomentose Lam. } & $\mathrm{R}$ & $\mathrm{Hu}$ & Internal parasites & $\begin{array}{l}\text { Root is dried \& powdered mixed with } \\
\text { water } 3 \text { tea sppon for } 3 \text { days }\end{array}$ & Oral \\
\hline & $\mathrm{L}$ & $\mathrm{Hu}$ & Tooth infection & $\begin{array}{l}\text { Leaf of Capparis tomentose \& Carisa } \\
\text { spinarum leave mixed together put on } \\
\text { infected tooth }\end{array}$ & Oral \\
\hline & $\mathrm{B} \& \mathrm{R}$ & $\mathrm{HU}$ & Malaria & $\begin{array}{l}\text { Crushed the Bark, root part and mixed } \\
\text { with water } 1 \text { cup of coffee }\end{array}$ & Oal \\
\hline & B \& R & Ls & Anthrax & $\begin{array}{l}\text { Crushed the Bark, root part and mixed } \\
\text { with water }\end{array}$ & Oral \\
\hline Celtis africana Burm.f. & $\mathrm{B}$ & $\mathrm{Hu}$ & TB & $\begin{array}{l}\text { Crushed \& Boild the bark, 1cup of tea } \\
\text { for 3days }\end{array}$ & Oral \\
\hline \multirow[b]{2}{*}{ Clematis simensis Fresen. } & $\mathrm{R}$ & $\mathrm{Hu}$ & Fever & $\begin{array}{l}\text { Crushed the root part and mixed with } \\
\text { water }\end{array}$ & Oral \\
\hline & $\mathrm{R}$ & Ls & $\begin{array}{l}\text { Internal parasites, } \\
\text { Anthrax }\end{array}$ & $\begin{array}{l}\text { Crushed the root part and mixed with } \\
\text { water }\end{array}$ & Oral \\
\hline \multirow{3}{*}{$\begin{array}{l}\text { Clerodendrum } \\
\text { myricoides ( Hochst.) } \\
\text { R.Br.ex vatke }\end{array}$} & $\mathrm{R}$ & $\mathrm{Hu}$ & $\begin{array}{l}\text { Liver, } \\
\text { Diarrhoea } \\
\text { cancer }\end{array}$ & $\begin{array}{l}\text { Crushed the root part and mixed with } \\
\text { water } 1 \text { cup of tea for } 7 \text { days for liver, } \\
3 \text { days diarrhea, } 7 \text { days for cancer }\end{array}$ & Oral \\
\hline & $\mathrm{R}$ & $\mathrm{Hu}$ & Tonsilites & $\begin{array}{l}\text { Crushed the root part } \& \text { mix with } \\
\text { water, } 1 / 2 \text { cup of coffee for } 1 \text { day }\end{array}$ & Oral \\
\hline & $\mathrm{R}$ & Ls & $\begin{array}{l}\text { Anthrax, } \\
\text { black leg }\end{array}$ & $\begin{array}{l}\text { Crushed the root part \& mixed with } \\
\text { water, } 1 \text { lit. for } 5 \text { days }\end{array}$ & Oral \\
\hline \multirow[b]{2}{*}{ Cordia africana Lam. } & $\mathrm{L}$ & $\mathrm{Hu}$ & Stomach problem & $\begin{array}{l}\text { Boil the leaves } \& \text { taken for } 3 \text { days } \\
\text { 1cup of coffee }\end{array}$ & Oral \\
\hline & $\mathrm{R}$ & Ls & Internal parasite & $\begin{array}{l}\text { Crushed the root part \& mixed with } \\
\text { water, } 1 \text { lit. for } 3 \text { days }\end{array}$ & Oral \\
\hline \multirow[t]{2}{*}{ Coriandrum sativum L. } & $\mathrm{L}$ & $\mathrm{Hu}$ & Malaria & $\begin{array}{l}\text { Crushed the Leaves \& mixed with } \\
\text { water, } 1 \text { cup of tea for } 3 \text { to } 5 \text { days }\end{array}$ & Oral \\
\hline & $\mathrm{L}$ & Ls & Anthrax & $\begin{array}{l}\text { Crushed the Leaves \& mixed with } \\
\text { water, } 1 \text { litt. For } 5 \text { days }\end{array}$ & Oral \\
\hline \multirow[b]{2}{*}{ Croton dichogomas Pax } & $\mathrm{L}$ & $\mathrm{Hu}$ & $\begin{array}{l}\text { Malaria, amoeba, } \\
\text { TB }\end{array}$ & $\begin{array}{l}\text { Crushed the Leaves \& mixed with } \\
\text { water }\end{array}$ & Oral \\
\hline & $\mathrm{L}$ & Ls & Anthrax & $\begin{array}{l}\text { Crushed the Leaves \& mixed with } \\
\text { water }\end{array}$ & Oral \\
\hline \multirow[b]{4}{*}{$\begin{array}{l}\text { Croton } \\
\text { Hochst. }\end{array}$} & $\mathrm{L}$ & $\mathrm{Hu}$ & Liver & $\begin{array}{l}\text { Crushed the leaves } \& \text { mixed with } \\
\text { water, } 1 / 2 \text { cup of coffee, for } 7 \text { days after } \\
4 \text { hrs milk will given }\end{array}$ & Oral \\
\hline & $\mathrm{L}$ & $\mathrm{Hu}$ & Kidney & $\begin{array}{l}\text { Crushed the leaves } \& \text { mixed with } \\
\text { water }, 1 / 2 \text { cup of coffee, for } 3 \text { days }\end{array}$ & Oral \\
\hline & $\mathrm{B}$ & $\mathrm{Hu}$ & Evil eye & Fumigate the leaves \& bark & Nasal \\
\hline & $\mathrm{B}$ & Ls & Internal parasites & $\begin{array}{l}\text { Crushed the leaves \& mixed with } \\
\text { water, } 1 \text { lit. for 1day }\end{array}$ & Oral \\
\hline $\begin{array}{l}\text { Cynoglosum lanceolatum } \\
\text { Forssk. }\end{array}$ & $\mathrm{L} \& \mathrm{R}$ & $\mathrm{Hu}$ & Cold, headache & $\begin{array}{l}\text { Crushed the leaves and root \& mix } \\
\text { with water, for lcup of tea until the } \\
\text { disease is cured }\end{array}$ & Oral \\
\hline
\end{tabular}




\begin{tabular}{|c|c|c|c|c|c|}
\hline Scientific & $\mathbf{P U}$ & Use & Diseases & Mode of preparation & $\begin{array}{l}\text { Route of } \\
\text { Add. }\end{array}$ \\
\hline & $\mathrm{L} \& \mathrm{R}$ & Ls & Hemorrhoids & $\begin{array}{l}\text { Crushed the leaves and root \& mix } \\
\text { with water then put on the infected } \\
\text { part of the body, age is factor }\end{array}$ & Dermal \\
\hline & $\mathrm{L} \& \mathrm{R}$ & Ls & Anthrax & $\begin{array}{l}\text { Crushed the leaves and root \& mix } \\
\text { with water }\end{array}$ & Oral \\
\hline \multirow{2}{*}{$\begin{array}{l}\text { Cyphostemma } \\
\text { adenocalule } \\
\text { ( Steud.ex A.Rich) } \\
\text { Desc.ex Wild \& Dr. }\end{array}$} & $\mathrm{R}$ & $\mathrm{Hu}$ & Wound & $\begin{array}{l}\text { Crushed the root part } \& \text { put on the } \\
\text { skin }\end{array}$ & Dermal \\
\hline & $\mathrm{R}$ & Ls & Internal parasites & $\begin{array}{l}\text { Crushed the root part \& mixed with } \\
\text { water }\end{array}$ & Oral \\
\hline \multirow[b]{2}{*}{ Datura stramonium L. } & $\mathrm{S}$ & $\mathrm{Hu}$ & Tooth ache & $\begin{array}{l}\text { Grind the seed \& ponded by the } \\
\text { leaves, put on infected tooth }\end{array}$ & Oral \\
\hline & $\mathrm{S}$ & $\mathrm{Hu}$ & Fungus & Grind the seed \& mixed with water & Dermal \\
\hline \multirow[b]{2}{*}{ Delonix elata (L.) } & $\mathrm{R}$ & $\mathrm{Hu}$ & $\begin{array}{l}\text { Asthma } \\
\text { (respiratory } \\
\text { complication) }\end{array}$ & $\begin{array}{l}\text { Crushed the root part } \& \text { mixed with } \\
\text { honey, } 1 \text { cup of tea for } 3 \text { days }\end{array}$ & Oral \\
\hline & $\mathrm{R}$ & Ls & Anthrax & $\begin{array}{l}\text { Crushed the root part \& mixed with } \\
\text { water, } 1 \text { lit. for } 5 \text { days }\end{array}$ & Oral \\
\hline \multirow{4}{*}{$\begin{array}{l}\text { Discopodium } \\
\text { penninervum (Hochest.) }\end{array}$} & $\mathrm{L}$ & $\mathrm{Hu}$ & Malaria & Crushed the leaves \& mix with water & Oral \\
\hline & $\mathrm{L}$ & $\mathrm{Hu}$ & Hemorrhoids & Crushed the leaves \& mix with water & Dermal \\
\hline & $\mathrm{L}$ & $\mathrm{Hu}$ & Common cold & Chewing the leaves & Oral \\
\hline & $\mathrm{L}$ & Ls & Anthrax & Crushed the leaves \& mix with water & Oral \\
\hline \multirow[b]{2}{*}{$\begin{array}{l}\text { Dovalis abyssinica } \\
\text { (A.Rich.)Warb. }\end{array}$} & $\mathrm{L} \& \mathrm{Fr}$ & $\mathrm{Hu}$ & Cold & $\begin{array}{l}\text { Crushed \& boil the leaves } \& \text { mix with } \\
\text { water }\end{array}$ & Oral \\
\hline & $\mathrm{L} \& \mathrm{Fr}$ & Ls & Internal parasites & $\begin{array}{l}\text { Crushed \& boil the leaves \& mix with } \\
\text { water }\end{array}$ & Oral \\
\hline \multirow[b]{2}{*}{$\begin{array}{l}\text { Echinopes angustilobus } \\
\text { S.moore }\end{array}$} & $\mathrm{L}$ & $\mathrm{Hu}$ & Skin itching & $\begin{array}{l}\text { Crushed the leaves part \& mixed with } \\
\text { water, for one week }\end{array}$ & Dermal \\
\hline & $\mathrm{L}$ & Ls & Stomach blotting & $\begin{array}{l}\text { Crushed the leaves part } \& \text { mixed with } \\
\text { water, } 1 / 2 \text { litter for } 2 \text { days }\end{array}$ & Oral \\
\hline $\begin{array}{l}\text { Ekebergia capensis } \\
\text { Sparm }\end{array}$ & $\mathrm{B}$ & $\mathrm{Hu}$ & TB & $\begin{array}{l}\text { Crushed the bark \& mixed with small } \\
\text { amount of water }\end{array}$ & Oral \\
\hline $\begin{array}{l}\text { Embelia schimperi } \\
\text { Vatke. }\end{array}$ & $\mathrm{Fr}$ & $\mathrm{Hu}$ & Tap worm & $\begin{array}{l}\text { Grind the dried fruit \& mixing with } \\
\text { Hagainia } a \text {. dried flower, } 1 / 2 \text { lit for } 1 \\
\text { month interval }\end{array}$ & Oral \\
\hline $\begin{array}{l}\text { Erythrina abyssinica } \\
\text { Lam.ex.Dc }\end{array}$ & $\begin{array}{l}\text { B \& } \\
\text { Fr }\end{array}$ & Ls & Eye disease & $\begin{array}{l}\text { Crushed the bark \& mixed with water } \\
\& \text { apply 2-3 drops }\end{array}$ & Optical \\
\hline \multirow{2}{*}{$\begin{array}{l}\text { Euclea schimperi ( Dc) } \\
\text { Dandy }\end{array}$} & $\mathrm{B}$ & $\mathrm{Hu}$ & Tinea nigra & Crushed the inner bark & Dermal \\
\hline & $\mathrm{R}$ & $\mathrm{Hu}$ & Internal parasite & Crushed the root part & Oral \\
\hline \multirow[b]{2}{*}{$\begin{array}{l}\text { Euphorbia abyssinica } \\
\text { Gmel }\end{array}$} & $\mathrm{L}$ & $\mathrm{Hu}$ & Diarrhea & $\begin{array}{l}\text { Crushed the leaves party \& mixed } \\
\text { with water }\end{array}$ & Oral \\
\hline & $\mathrm{L}, \mathrm{B}, \mathrm{R}$ & Ls & Stomach blotting & $\begin{array}{l}\text { Crushed the dried all part of the plant, } \\
\text { fumigant, for } 2 \text { days }\end{array}$ & Nasal \\
\hline Euphorbia depauperata & $\mathrm{R}$ & $\mathrm{Hu}$ & Stomach ache & $\begin{array}{l}\text { Crushed the root, mixed with water. } \\
1 \text { cup of tea }\end{array}$ & Oral \\
\hline Ficus thonningii Blume & $\mathrm{L}$ & $\mathrm{Hu}$ & Sudden sickness & $\begin{array}{l}\text { Crushed the leaves } \& \text { mix with salt } \\
\text { and water. } 1 / 2 \text { lit. for } 2 \text { days }\end{array}$ & Oral \\
\hline \multirow[b]{2}{*}{$\begin{array}{l}\text { Galneria saxifrage } \\
\text { (Hochest.) Bridson }\end{array}$} & $\mathrm{L} \& \mathrm{~B}$ & $\mathrm{Hu}$ & Malaria, TB & $\begin{array}{l}\text { Crushed the bark, leaf \& mix with } \\
\text { water } 1 \text { cup of coffee }\end{array}$ & Oral \\
\hline & $\mathrm{L} \& \mathrm{~B}$ & Ls & Anthrax & $\begin{array}{l}\text { Crushed the bark, leaf \& mix with } \\
\text { water }\end{array}$ & Oral \\
\hline \multirow{4}{*}{$\begin{array}{l}\text { Grewia ferruginea } \\
\text { Hochst.Ex A. Rich }\end{array}$} & B & $\mathrm{Hu}$ & Malaria, Diabetes & Crushed the bark \& mix with water & Oral \\
\hline & $\mathrm{B}$ & $\mathrm{Hu}$ & Tooth ache & Chewing the bark & Oral \\
\hline & $\mathrm{B}$ & $\mathrm{Hu}$ & Hemorrhoids & $\begin{array}{l}\text { Crushed the bark \& mix with water, } \\
\text { put on the infected body }\end{array}$ & Dermal \\
\hline & $\mathrm{B}$ & Ls & Anthrax, cough & Crushed the bark \& mix with water & Oral \\
\hline $\begin{array}{l}\text { Hagenia abyssinica } \\
\text { (Bruce)J.F.Gmelin }\end{array}$ & $\mathrm{Fl}$ & $\mathrm{Hu}$ & Tap worm & $\begin{array}{l}\text { Crushed the dried flower \& mixed } \\
\text { with (B)Croton } \mathrm{m} \text {. and Embelia s. } \\
\text { (S) } 1 / 2 \text { cup of tea for } 15 \text { days interval }\end{array}$ & Oral \\
\hline $\begin{array}{l}\text { Hypericum quartinianum } \\
\text { A.Rich. }\end{array}$ & $\mathrm{L}$ & $\mathrm{Hu}$ & Hemorrhoids & Crused the leaves \& mix with water. & Oral \\
\hline
\end{tabular}




\begin{tabular}{|c|c|c|c|c|c|}
\hline Scientific & $\mathbf{P U}$ & Use & Diseases & Mode of preparation & $\begin{array}{l}\text { Route of } \\
\text { Add. }\end{array}$ \\
\hline & $\mathrm{L}$ & Ls & Anthrax & $\begin{array}{l}\text { Crused the leaves \& mix with } \\
\text { Vernonia } a \text {. and water. } 1 / 2 \text { lit. for } 5 \\
\text { days }\end{array}$ & Oral \\
\hline $\begin{array}{l}\text { Juniprus procera } \\
\text { Hochest. Ex. Endl. }\end{array}$ & B & $\mathrm{Hu}$ & Tooth ache & $\begin{array}{l}\text { Powder of the bark, mixed with } \\
\text { Rumex nepalensis }\end{array}$ & Oral \\
\hline \multirow{4}{*}{$\begin{array}{lr}\text { Justicia } & \text { schimperiana } \\
\text { (Hochst.ex } & \text { Nees) } \\
\text { T.Anders. } & \\
\end{array}$} & $\mathrm{L}$ & $\mathrm{Hu}$ & Common cold & $\begin{array}{l}\text { The leaves warm on fire and put on } \\
\text { face }\end{array}$ & $\begin{array}{l}\text { Nasal, } \\
\text { dermal }\end{array}$ \\
\hline & $\mathrm{L}$ & $\mathrm{Hu}$ & Asthma & Leaf mixed with water & Oral \\
\hline & $\mathrm{L}$ & $\mathrm{Hu}$ & Liver & $\begin{array}{l}\text { Crushed the leaves \& mixed with } \\
\text { Croton } m \text {. leaves, for } 7 \text { days }\end{array}$ & Oral \\
\hline & $\mathrm{L}$ & Ls & Skin itching & $\begin{array}{l}\text { Crushed the leaves \& wash their } \\
\text { bodies 3-4 days }\end{array}$ & Dermal \\
\hline \multirow[b]{2}{*}{$\begin{array}{l}\text { Kalanchoe } \\
\text { A.Rich. }\end{array}$} & $\mathrm{L}$ & $\mathrm{Hu}$ & $\begin{array}{l}\text { Cough, common } \\
\text { cold, swelling }\end{array}$ & $\begin{array}{l}\text { Boiled the leaves \& take } 1 \text { cup } \& \\
\text { warm the leaves on fire } \& \text { put on the } \\
\text { swelling part of the body }\end{array}$ & $\begin{array}{l}\text { Oral } \quad \& \\
\text { dermal }\end{array}$ \\
\hline & $\mathrm{L}$ & Ls & Anthrax & $\begin{array}{l}\text { Crushed the leaf ,mixed with } \\
\text { Phytolacca dodecandra }\end{array}$ & Oral \\
\hline \multirow[b]{2}{*}{$\begin{array}{l}\text { Lippia adoensis Hochst } \\
\text { ex.Walp. }\end{array}$} & $\mathrm{L}$ & $\mathrm{Hu}$ & Fever & $\begin{array}{l}\text { Boild the leaves } \& \text { mixed with Ruta, } \\
\text { Ocimum } 2 \text { twice daily } 1 / 2 \text { cup of coffee }\end{array}$ & Oral \\
\hline & $\mathrm{L}$ & Ls & Internal parasites & $\begin{array}{l}\text { Boild the leaves \& mixed with Ruta } \\
\text { c., Ocimum } l \text {. leaves } 1 \text { litter for } 3 \text { days }\end{array}$ & Oral \\
\hline \multirow[b]{2}{*}{$\begin{array}{l}\text { Maesa Lanceolata } \\
\text { Forssk. }\end{array}$} & $\mathrm{L}$ & $\mathrm{Hu}$ & Headache & $\begin{array}{l}\text { Crushed the leaves \& mixed with } \\
\text { water, } 1 \text { cup of tea, for } 1 \text { day }\end{array}$ & Oral \\
\hline & $\mathrm{L}$ & Ls & Mastitis & $\begin{array}{l}\text { Crushed the leaves \& mixed with } \\
\text { water, washing for } 4 \text { days }\end{array}$ & Dermal \\
\hline Malva verticillatum L. & $\mathrm{L}$ & $\mathrm{Hu}$ & Internal parasites & $\begin{array}{l}\text { Crushed the leaves \& mixed with } \\
\text { water }\end{array}$ & Oral \\
\hline Maytenus addat (Looes.) & $\mathrm{L}$ & $\mathrm{Hu}$ & Diarrhea, & $\begin{array}{l}\text { Crushed the leaves \& mixed with } \\
\text { water }\end{array}$ & Oral \\
\hline $\begin{array}{l}\text { Maytenus arbutifolia } \\
\text { (A.Rich.) Wilczek }\end{array}$ & $\mathrm{L}$ & $\mathrm{Hu}$ & Diarrhea, & $\begin{array}{l}\text { Crushed the leaves \& mixed with } \\
\text { water }\end{array}$ & Oral \\
\hline $\begin{array}{l}\text { Milletia ferruginea } \\
\text { (Hochst.) Bakk. }\end{array}$ & $\mathrm{B}$ & $\mathrm{Hu}$ & Skin itching & Crushed bark \& mixed with water & Dermal \\
\hline Mimusops kummel A.DC. & $\mathrm{L}$ & $\mathrm{Hu}$ & Stomach ache & $\begin{array}{l}\text { Crushed the leaves \& mixed with } \\
\text { water }\end{array}$ & Oral \\
\hline \multirow[b]{2}{*}{$\begin{array}{l}\text { Moringa stenopetala } \\
\text { (Bok.f.) cuf }\end{array}$} & $\mathrm{L}$ & $\mathrm{Hu}$ & Blood pressure & $\begin{array}{l}\text { Boiled with water, taken 1cup of tea } \\
\text { every } 2 \text { days }\end{array}$ & Oral \\
\hline & $\mathrm{L}$ & Ls & Anthrax & $\begin{array}{l}\text { Crushed the leaves \& mixed with } \\
\text { water }\end{array}$ & Oral \\
\hline Myrica salcifolia A.Rich. & $\mathrm{B}$ & $\mathrm{Hu}$ & Prostate problem & Crushed the bark \& mixed with water & Oral \\
\hline Myrsine africana $\mathrm{L}$. & $\mathrm{S}$ & $\mathrm{Hu}$ & Stomach ache & $\begin{array}{l}\text { Seeds are crushed, mixed with water, } \\
\text { tea spoon }\end{array}$ & Oral \\
\hline $\begin{array}{l}\text { Myrsine melanophlous } \\
\text { (L.) R.Br. }\end{array}$ & $\mathrm{B}$ & $\mathrm{Hu}$ & Stomach problem & Crushed the bark \& mixed with water & Oral \\
\hline \multirow[b]{2}{*}{$\begin{array}{l}\text { Nuxia congesta R.Br. ex } \\
\text { Fresen }\end{array}$} & $\mathrm{B}$ & $\mathrm{Hu}$ & Stomach & $\begin{array}{l}\text { Crushed the bark of Nuxia c. \& } \\
\text { Shifleria a. \& boiling in the water, } \\
\text { based on age for } 5 \text { days }\end{array}$ & Oral \\
\hline & $\mathrm{B}$ & Ls & Anthrax & $\begin{array}{l}\text { Crushed the bark of Nuxia c. \& } \\
\text { Shifleria a. \& boiling in the water, } \\
\text { 1lit. for }\end{array}$ & Oral \\
\hline Ocimum basilicum L. & $\mathrm{L}$ & $\mathrm{Hu}$ & Stomach & $\begin{array}{l}\text { Crushed the leaves \& mixed with } \\
\text { water, cup of tea } 2 \text { days }\end{array}$ & Oral \\
\hline \multirow[b]{2}{*}{ Ocimum gratisimum L. } & $\mathrm{L}$ & $\mathrm{Hu}$ & $\begin{array}{l}\text { Malaria, common } \\
\text { cold }\end{array}$ & $\begin{array}{l}\text { Crushed the leaves \& mixed with } \\
\text { water, } 1 / 2 \text { tea spoon, for } 1 \text { day }\end{array}$ & Oral \\
\hline & $\mathrm{L}$ & Ls & Anthrax & $\begin{array}{l}\text { Crushed the leaves \& mixed with } \\
\text { water, } 1 / 2 \text { liter, for } 1 \text { day }\end{array}$ & Oral \\
\hline \multirow[b]{2}{*}{$\begin{array}{l}\text { Ocimum lamiifolium } \\
\text { Hochst.ex Benth. }\end{array}$} & $\mathrm{L}$ & $\mathrm{Hu}$ & Stomach problem, & $\begin{array}{l}\text { Crushed the leaves \& mixed with } \\
\text { water, } 1 \text { tea spoon with coffee, for } 2 \text { - } \\
3 \text { day }\end{array}$ & Oral \\
\hline & $\mathrm{L}$ & $\mathrm{Hu}$ & Common cold & $\begin{array}{l}\text { Crushed the leaves \& mixed with } \\
\text { water, 3-5 drops }\end{array}$ & Nasal \\
\hline
\end{tabular}




\begin{tabular}{|c|c|c|c|c|c|}
\hline Scientific & $\mathbf{P U}$ & Use & Diseases & Mode of preparation & $\begin{array}{l}\text { Route of } \\
\text { Add. }\end{array}$ \\
\hline \multirow[b]{2}{*}{$\begin{array}{l}\text { Ocimum } \\
\text { Roth. }\end{array}$} & $\mathrm{L}$ & $\mathrm{Hu}$ & $\begin{array}{l}\text { Stomach problem, } \\
\text { mich }\end{array}$ & $\begin{array}{l}\text { Crushed the leaves } \& \text { mixed with } \\
\text { water, } 1 / 2 \text { cup of coffee, for } 2-3 \text { day }\end{array}$ & Oral \\
\hline & $\mathrm{L}$ & $\mathrm{Hu}$ & Eye infection & $\begin{array}{l}\text { Crushed the leaves \& mixed with } \\
\text { water, } 2-3 \text { drops }\end{array}$ & Optical \\
\hline $\begin{array}{l}\text { Olea europea } \\
\text { subsp.cuspidata } \mathrm{L} .\end{array}$ & $\mathrm{S}$ & $\mathrm{Hu}$ & Wound & Warm the fresh stem on fire & Dermal \\
\hline \multirow[b]{2}{*}{ Olinia rochetiana A.Juss. } & $\mathrm{L}$ & $\mathrm{Hu}$ & TB & $\begin{array}{l}\text { Crushed the Leaves, mixed with } \\
\text { water }\end{array}$ & Oral \\
\hline & $\mathrm{L}$ & $\mathrm{Hu}$ & Cold & $\begin{array}{l}\text { Boiled Leaves , mixed with water, } \\
\text { then wash all body }\end{array}$ & Dermal \\
\hline $\begin{array}{l}\text { Opuntia ficus-indica (L.) } \\
\text { Miller. }\end{array}$ & $\mathrm{L}$ & $\mathrm{Hu}$ & Fungus & $\begin{array}{l}\text { Washing their hair by the sap of the } \\
\text { leaves }\end{array}$ & Dermal \\
\hline Plectranthus marrubatus & $\mathrm{R}$ & $\mathrm{Hu}$ & Internal & Crushed the root, mixed with water & Oral \\
\hline \multirow[b]{2}{*}{$\begin{array}{l}\text { Phytolacca dodecandra } \mathrm{L} \\
\text { Her. }\end{array}$} & $\mathrm{R}$ & $\mathrm{Hu}$ & Malaria & $\begin{array}{l}\text { Crushed the root, mixed with water } \\
\text { for } 3 \text { days }\end{array}$ & Oral \\
\hline & $\mathrm{R}$ & $\mathrm{Hu}$ & Rabies & $\begin{array}{l}\text { Crushed root, mixed with Justicia } \\
\text { schimperiana \& water }\end{array}$ & Oral \\
\hline \multirow{2}{*}{$\begin{array}{l}\text { Prunus africana } \\
\text { (Hook.f)Kalkm }\end{array}$} & $\mathrm{B}$ & $\mathrm{Hu}$ & $\begin{array}{l}\text { Prostate problem, } \\
\text { tap worm, cold }\end{array}$ & Crushed the bark \& mixed with water & Oral \\
\hline & $\mathrm{B}$ & Ls & Internal parasite & Crushed the bark \& mixed with water & Oral \\
\hline $\begin{array}{l}\text { Psydrax schimperiana } \\
\text { (A.Rich.) Bridson }\end{array}$ & $\mathrm{R}$ & $\mathrm{Hu}$ & Diarrhoea & Crushed root, mixed & Oral \\
\hline \multirow[b]{2}{*}{ Plantago lanceolata L. } & $\mathrm{L}$ & $\mathrm{Hu}$ & Skin cut & $\begin{array}{l}\text { Crushed the leaves and add 3-4drops } \\
\text { on the skin }\end{array}$ & Dermal \\
\hline & $\mathrm{L}$ & $\mathrm{Hu}$ & Gastritis, cough & $\begin{array}{l}\text { Crushed the leaves \& take } 3 \text { times a } \\
\text { day }\end{array}$ & Oral \\
\hline Rhus tenuinervis Engl. & $\mathrm{L}$ & Ls & Stomach blotting & Crushed the leaves, mixed with water & Oral \\
\hline \multirow[b]{2}{*}{ Ricinus communis L. } & $\mathrm{S}$ & $\mathrm{Hu}$ & Wound & Grind the seed, put on the wound & Dermal \\
\hline & $\mathrm{S}$ & $\mathrm{Hu}$ & Stomach ache & Grind the seed for laxative property & Oral \\
\hline $\begin{array}{l}\text { Rubus } \quad \text { steudneri } \\
\text { Schweinf. }\end{array}$ & $\mathrm{Fr}$ & $\mathrm{Hu}$ & Internal parasite & $\begin{array}{l}\text { Crushed the fruit part, mixed with } \\
\text { water }\end{array}$ & Oral \\
\hline Rumex abyssinica Jacq. & $\mathrm{R}$ & $\mathrm{Hu}$ & Ascaris & $\begin{array}{l}\text { Crushed the root, mixed with small } \\
\text { amount of water }\end{array}$ & Oral \\
\hline \multirow{2}{*}{$\begin{array}{l}\text { Rumex nepalensis } \\
\text { Spreng. }\end{array}$} & $\mathrm{R}$ & $\mathrm{Hu}$ & Tinea nigra & $\begin{array}{l}\text { Crushed the root part \& mix with salt, } \\
2 \text { days interval until the fungus is } \\
\text { removed }\end{array}$ & Dermal \\
\hline & $\mathrm{R}$ & $\mathrm{Hu}$ & Internal parasite & Crushed the root part \& mix with & Oral \\
\hline Ruta chalepensis L. & $\mathrm{L}$ & $\mathrm{Hu}$ & Stomach problem & $\begin{array}{l}\text { Chewing or boiled the leaves \& } \\
\text { mixed with coffee ot tea }\end{array}$ & Oral \\
\hline $\begin{array}{l}\text { Saliva nilotica Juss.ex } \\
\text { Jacq. }\end{array}$ & $\mathrm{L}$ & $\mathrm{Hu}$ & Skin etching & $\begin{array}{l}\text { Crushed the leaves } \& \text { rub the skin for } \\
2-3 \text { days }\end{array}$ & Dermal \\
\hline Senna septromolisis & $\mathrm{L}$ & $\mathrm{Hu}$ & Snake bite & $\begin{array}{l}\text { Crushed the Leaves, put on infected } \\
\text { body }\end{array}$ & Dermal \\
\hline \multirow[b]{2}{*}{ Schefflera abyssinica } & $\mathrm{B}$ & $\mathrm{Hu}$ & Tooth ache & Chewing the bark of the plant & Oral \\
\hline & $\mathrm{B}$ & Ls & Anthrax & Crushed the bark \& mixed with water & Oral \\
\hline Sida rhombifolia $\mathrm{L}$. & $\mathrm{R}$ & $\mathrm{Hu}$ & $\begin{array}{l}\text { Asthma \& other } \\
\text { respiratory } \\
\text { complaints }\end{array}$ & Root powder is employed & Oral \\
\hline \multirow[b]{2}{*}{ Senecio gigas Vatke } & $\mathrm{L}$ & $\mathrm{Hu}$ & Diarrhea & Crushed the leaves, mixed with water & Oral \\
\hline & $\mathrm{L}$ & $\mathrm{Hu}$ & Wound & $\begin{array}{l}\text { Crushed the leaves \& put on the } \\
\text { infected part }\end{array}$ & Dermal \\
\hline $\begin{array}{l}\text { Solansio myriocephalus } \\
\text { Sch. Bip. }\end{array}$ & $\mathrm{L}$ & $\mathrm{Hu}$ & Internal parasite & Crushed the leaves, mixed with water & Oral \\
\hline Solanum anguivi Lam. & S\& L & $\mathrm{Hu}$ & Tuberculosis & $\begin{array}{l}\text { Leaves \& seed powder mixed with } \\
\text { honey, tea spoon }\end{array}$ & Oral \\
\hline Solanum incanum L. & $\mathrm{Fr}$ & $\mathrm{Hu}$ & Tonsillitis & $\begin{array}{l}\text { By squeezing the fruit juice }, 3 \text { fruit are } \\
\text { enough for } 3 \text { days }\end{array}$ & Oral \\
\hline Solanum marginatum L.f. & Fr & $\mathrm{Hu}$ & TB, cough, cold & $\begin{array}{l}\text { Cooked the leaf } \& \text { seeds, } 1 / 2 \text { cup of } \\
\text { coffee for } 3 \text { days }\end{array}$ & Oral \\
\hline
\end{tabular}




\begin{tabular}{|c|c|c|c|c|c|}
\hline Scientific & $\mathbf{P U}$ & Use & Diseases & Mode of preparation & $\begin{array}{l}\text { Route of } \\
\text { Add. }\end{array}$ \\
\hline \multirow[b]{2}{*}{ Spilanthes uliginosa SW. } & $\mathrm{R} \& \mathrm{~F}$ & $\mathrm{Hu}$ & Tooth ache & $\begin{array}{l}\text { Chewing the root or the flower part of } \\
\text { the plant }\end{array}$ & Oral \\
\hline & $\begin{array}{l}\mathrm{L}, \mathrm{B} \& \\
\mathrm{r}\end{array}$ & $\mathrm{Hu}$ & Stomach ache & Crushed all parts, mixed with water & Oral \\
\hline $\begin{array}{lr}\text { Stephania } & \text { abyssinica } \\
\text { (Dillon \& } & \text { A.Rich.). } \\
\text { Walp. } & \\
\end{array}$ & $\mathrm{R}$ & $\mathrm{Hu}$ & Diarrhea & Root powder mixed with water & Oral \\
\hline $\begin{array}{l}\text { Syzgium } \\
\text { (willd.)Dc. }\end{array}$ & $\mathrm{L}$ & $\mathrm{Hu}$ & Cough, etching & $\begin{array}{l}\text { Leaves boiled and taken 1 cup of tea } \\
\text { and take a shower for two days } \\
\text { accordingly }\end{array}$ & $\begin{array}{l}\text { Oral } \quad \& \\
\text { Dermal }\end{array}$ \\
\hline $\begin{array}{l}\text { Teclea simplicifolia } \\
\text { (Engl.) Verdoorn. }\end{array}$ & $\mathrm{L}$ & $\mathrm{Hu}$ & Stomach & $\begin{array}{l}\text { Crushed the leaves \& mixed with } \\
\text { water }\end{array}$ & Oral \\
\hline \multirow[b]{5}{*}{ Teclea nobils Del. } & $\mathrm{L}, \& \mathrm{~B}$ & $\mathrm{Hu}$ & Tooth ache & $\begin{array}{l}\text { Crushed and pounded the leaves \& } \\
\text { bark, put on infected tooth }\end{array}$ & Oral \\
\hline & $\mathrm{L}$ & $\mathrm{Hu}$ & Wound & Crushed the leaves \& put on wound & Dermal \\
\hline & $\mathrm{L}$ & $\mathrm{Hu}$ & Stomach & $\begin{array}{l}\text { Crushed the leaves \& mixed with } \\
\text { water, } 1 \text { cup of coffee }\end{array}$ & Oral \\
\hline & $\mathrm{L}$ & $\mathrm{Hu}$ & Headache & $\begin{array}{l}\text { Crushed the leaves } \& \text { mixed with } \\
\text { water } 1 / 2 \text { cup of coffee for } 1 \text { day }\end{array}$ & Oral \\
\hline & $\mathrm{L} \& \mathrm{~B}$ & Ls & Stomach blotting & $\begin{array}{l}\text { Crushed the leaves \& mixed with } \\
\text { water, Vernonia a. } 1 \text { lit. for } 1 \text { to } 2 \text { days }\end{array}$ & Oral \\
\hline Urtica simensis Steudel & $\mathrm{L}$ & $\mathrm{Hu}$ & Gastritis & Boild the leaves \& take as a food & Oral \\
\hline $\begin{array}{l}\text { Urera hypselodendron } \\
\text { (A.Rich) }\end{array}$ & $\mathrm{L}$ & $\mathrm{Hu}$ & Internal parasite & $\begin{array}{l}\text { Crushed the leaves \& mixed with } \\
\text { water }\end{array}$ & Oral \\
\hline \multirow[b]{3}{*}{$\begin{array}{l}\text { Vernonia } \\
\text { Del. }\end{array}$} & \multirow[t]{2}{*}{$\mathrm{L}$} & \multirow[t]{2}{*}{$\mathrm{Hu}$} & $\begin{array}{l}\text { Malaria, } \\
\text { Diarrhoea, TB, }\end{array}$ & $\begin{array}{l}\text { Boiling the leaves \& mixed with } \\
\text { water \& Ruta, } 1 \text { glass for } 2 \text { to } 3 \text { days }\end{array}$ & Oral \\
\hline & & & Etching & $\begin{array}{l}\text { Boiling the leaves \& mixed with } \\
\text { water,washing with } 1 \text { buckt, for } 3 \text { days }\end{array}$ & Dermal \\
\hline & $\mathrm{L}$ & Ls & $\begin{array}{l}\text { Anthrax, stomach } \\
\text { blotting }\end{array}$ & $\begin{array}{l}\text { Leaves mixed with salt \& water, } 1 \text { lit. } \\
\text { for } 1 \text { to } 3 \text { days }\end{array}$ & Oral \\
\hline urticifolia & $\mathrm{L}$ & Ls & Stomach blotting & $\begin{array}{l}\text { Crushed the leaves \& mix with water, } \\
1 \text { lit for } 2-3 \text { days }\end{array}$ & Oral \\
\hline \multirow{4}{*}{$\begin{array}{l}\text { Withania somenifera (L.) } \\
\text { Dunal in DC. }\end{array}$} & $\mathrm{R}$ & $\mathrm{Hu}$ & Malaria & Crushed the root part of the plant & Oral \\
\hline & $\mathrm{R}$ & $\mathrm{Hu}$ & Stomache problem & $\begin{array}{l}\text { Chewing the root part at early in the } \\
\text { morning }\end{array}$ & Oral \\
\hline & $\mathrm{B}$ & $\mathrm{Hu}$ & Swelling & $\begin{array}{l}\text { Bark powder mixed with butter(anti- } \\
\text { inflammatory) }\end{array}$ & Dermal \\
\hline & $\mathrm{R}$ & Ls & Anthrax & Crushed the root part of the plant & Oral \\
\hline Ximenia americana $\mathrm{L}$. & $\mathrm{R}$ & $\mathrm{Hu}$ & Tooth ache & Chewing the bark of the root & Oral \\
\hline $\begin{array}{l}\text { Ziziphus spina-christi } \\
\text { (L.) Desf. }\end{array}$ & $\mathrm{Fr}$ & $\mathrm{Hu}$ & Stomach ache & Chewing the fruit & Oral \\
\hline
\end{tabular}

